ISSN 2075-4701

www.mdpi.com/journal/metals/

Review

\title{
Nanotoxicology of Metal Oxide Nanoparticles
}

\author{
Amedea B. Seabra ${ }^{1,2, \dagger, *}$ and Nelson Durán ${ }^{2,3,4, \dagger}$
}

1 Exact and Earth Sciences Department, Universidade Federal de São Paulo, Rua São Nicolau, 210, Diadema, São Paulo 0991330, Brazil

2 Laboratory of Nanomaterials Synthesis and Biological Interactions (NanoBioss), Institute of Chemistry, Universidade Estadual de Campinas, Campinas, São Paulo 13083970, Brazil; E-Mail: duran@iqm.unicamp.br

3 Institute of Chemistry, Biological Chemistry Laboratory, Universidade Estadual de Campinas, Campinas, São Paulo 13083970, Brazil

4 Brazilian Nanotechnology National Laboratory (LNNano), CNPEM, Campinas, São Paulo 13083-970, Brazil

$\dagger$ These authors contributed equally to this work.

* Author to whom correspondence should be addressed; E-Mail: amedea.seabra@unifesp.br or amedea.seabra@gmail.com; Tel.: +55-11-3319-3550; Fax: +55-11-3319-3400.

Academic Editor: Nikolaos Michailidis

Received: 8 April 2015 / Accepted: 26 May 2015 / Published: 3 June 2015

\begin{abstract}
This review discusses recent advances in the synthesis, characterization and toxicity of metal oxide nanoparticles obtained mainly through biogenic (green) processes. The in vitro and in vivo toxicities of these oxides are discussed including a consideration of the factors important for safe use of these nanomaterials. The toxicities of different metal oxide nanoparticles are compared. The importance of biogenic synthesized metal oxide nanoparticles has been increasing in recent years; however, more studies aimed at better characterizing the potent toxicity of these nanoparticles are still necessary for nanosafely considerations and environmental perspectives. In this context, this review aims to inspire new research in the design of green approaches to obtain metal oxide nanoparticles for biomedical and technological applications and to highlight the critical need to fully investigate the nanotoxicity of these particles.
\end{abstract}


Keywords: nanotoxicity; metal oxide nanoparticles; biogenic nanoparticles; cytotoxicity; in vivo toxicity and ecotoxicity

\section{Introduction}

Metal oxide nanoparticles have wide applications, primarily in the technology field, including their use as a semiconductor, electroluminescent or thermoelectric material, but they are also used in biomedical applications as drug delivery systems for treatment and diagnosis and in environmental decontamination applications [1,2]. The classical methods for obtaining metal oxide nanoparticles are based on chemical and physical techniques that employ hazardous and expensive chemicals with high energy input and a negative effect on the environment [1]. The production of metal oxide nanoparticles via biogenic synthesis has received increasing attention recently because it is a novel process for the development of engineered materials [3]. The biogenic synthesis of nanomaterials by different organisms offers a reliable, low-cost and environment friendly alternative approach compared with classical chemical and/or physical methods [3-8]. The biogenic synthesis of metallic nanoparticles leads to the formation of capped nanostructures with proteins/biomolecules from the organism during the biosynthesis. These capping agents prevent nanoparticle aggregation and likely play an important role in the stabilization of the nanosystem. The presence of capping agents may improve the biocompatibility of biogenic nanomaterials [3-8]. Figure 1 shows a schematic representation of the simplicity of biogenic synthesis of metal oxide nanoparticles along with the advantages and disadvantages of green processes.

\section{Biogenic Synthesis of Metal Oxide Nanoparticles}

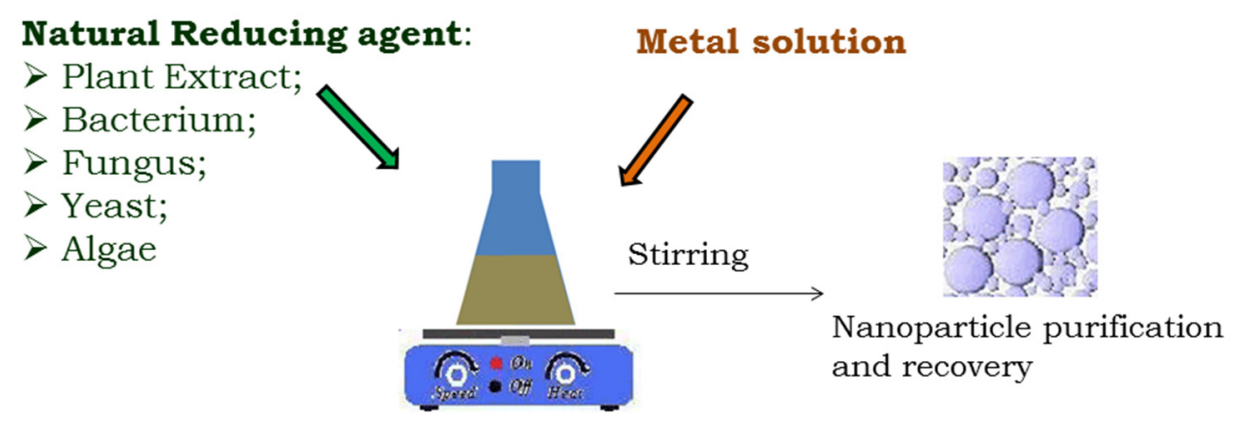

Advantages

$\checkmark$ Room temperature;

$\checkmark$ Room atmosphere;

$\checkmark$ No toxic solvent;

$\checkmark$ No expensive equipment;

$\checkmark$ Environment friendly technology;

$\checkmark$ Cost-effective
Disadvantages

$\checkmark$ The exact mechanism for synthesis of nanoparticles needs to be elucidated;

$\checkmark$ Limitations to scale up production processes;

$\checkmark$ Reproducibility of the processes

Figure 1. Schematic representation of the biogenic synthesis of metal oxide nanoparticles and its advantages and disadvantages. 
As highlighted in Figure 1, biogenic methods to obtain metal oxide nanoparticles are performed at room conditions, in a simple and cost effective manner and with no contamination to the environment. However, the main disadvantages are the limitations related to the scaling up the syntheses processes. In addition, the reproducibility of the biogenic processes needs to be improved, and in most of the cases, the mechanisms of nanoparticle formation are not completely elucidated [3-8].

The increasing production and use of metal oxide nanoparticles in numerous applications leads to adverse effects on health [9]. Several studies have demonstrated nanoparticle toxicity and increased cytotoxic potential of these materials [10]. However, a better understanding of the biological mechanisms of cytotoxicity and/or genotoxicity is necessary [11]. Silver nanoparticles are the most studied metallic nanoparticles but their cytotoxicity and genotoxicity are not fully understood [10,12-15]. The toxicity of more complex nanostructures, such as graphene and carbon nanotubes, is also uncertain [16].

This review describes the biogenic synthesis of important metal oxide nanoparticles and their cytotoxicity in vivo and in vitro. The safety implications and environment effects of these nanoparticles are also discussed.

\section{Biogenic Synthesis of Metal Oxide Nanoparticles}

This section describes the biogenic routes (green approaches) to synthesize different metal oxide nanoparticles. These particles are important for technological, biomedical and environmental applications.

\subsection{Bismuth Trioxide (Bi2 $\left.\mathrm{O}_{3}\right)$ Nanocrystals}

$\mathrm{Bi}_{2} \mathrm{O}_{3}$ nanocrystals are an optoelectronic material. This metal oxide has attracted a great deal of attention as a semiconductor that is sensitive to visible light and has superior photocatalytic activity for environmental purposes, such as water treatment [17]. The traditional methods used to obtain $\mathrm{Bi}_{2} \mathrm{O}_{3}$ require the addition of organic/toxic solvents and high temperatures [17,18]. Uddin et al. [19] reported the room temperature biosynthesis of monodisperse $\mathrm{Bi}_{2} \mathrm{O}_{3}$ nanoparticles $(5-10 \mathrm{~nm})$ by Fusarium oxysporum as an alternative to conventional chemical methods. An important advantage of this ecofriendly biosynthesis is the formation of $\mathrm{Bi}_{2} \mathrm{O}_{3}$ nanoparticles with a protein layer, in contrast to the delicate surface coating that is obtained by using the conventional chemical methods, which are not capable of providing thermal stability or avoiding the agglomeration of nanoparticles.

\subsection{Cobalt Oxide $\left(\mathrm{Co}_{3} \mathrm{O}_{4}\right)$ Nanocrystals}

$\mathrm{Co}_{3} \mathrm{O}_{4}$ nanomaterials possess desirable optical, magnetic and electrochemical properties and have been used as a super capacitor in energy storage devices. The classical methods of synthesis are solvothermal and thermal decomposition and the use of templates [20-22]. These synthetic routes are costly, time-consuming and toxic.

The microbial synthesis of $\mathrm{Co}_{3} \mathrm{O}_{4}$ nanoparticles using the marine bacterium Brevibacterium casei, was described by Kumar et al. [23]. This was likely the first study in which the quantitative and qualitative analyses that were conducted during the biogenic synthesis indicated the sensitivity of the 
micromechanical properties of cells to the surrounding toxic environment. Transmission electron microscopy (TEM) of the as-synthesized nanoparticles revealed the quasi-spherical morphology of the particles with an average size of $6 \mathrm{~nm}$. The protein coating on the biogenic $\mathrm{Co}_{3} \mathrm{O}_{4}$ nanoparticles reduced agglomeration and conserved the identity of the isolated nanoparticles [23].

\subsection{Copper Oxide (CuO, $\left.\mathrm{Cu}_{2} \mathrm{O}\right)$ Nanoparticles}

Copper and copper oxide nanoparticles are used in optical and electronics applications and are a promising antimicrobial agent [5,24]. Several researchers have described the biogenic synthesis of copper based nanoparticles for a variety of applications. Hasan et al. [25] demonstrated that Serratia sp. produces an intracellular mixture of metallic copper and different copper oxides. Copper oxide $\left(\mathrm{Cu}_{2} \mathrm{O}\right)$ nanoparticles $(10-20 \mathrm{~nm})$ were synthesized at room temperature using the baker's yeast Saccharomyces cerevisiae [26]. The proposed mechanism is based on the partial gaseous hydrogen pressure of the reduction potential of metallic ions, which indicates the dependence of membrane bound oxido-reductases [26].

Usha et al. [27] reported the synthesis of copper oxide by Streptomyces sp. for antimicrobial applications in textiles. Copper oxide nanoparticles $(100-150 \mathrm{~nm})$ were obtained in solution by the reduction of copper sulfate by the reductase enzymes of the microorganism. The authors demonstrated the antibacterial (against Escherichia coli (E. coli) and Staphylococcus aureus (S. aureus)) and antifungal (against Aspergillus niger) efficacies of nanoparticle-coated fabrics. Scanning electron microscopy (SEM) revealed nanoparticles embedded on the treated fabric textile. The durability of the finished fabric was evaluated [27]. Singh et al. [28] reported the biological synthesis (E. coli) of copper oxide nanoparticles with different sizes $(10-40 \mathrm{~nm}$, plus aggregates $)$ and shapes (quasi-spherical). The results indicated the presence of a mixture of $\mathrm{Cu}_{2} \mathrm{O}$ and $\mathrm{CuO}$ phases. The proteins secreted by E. coli, with molecular weights ranging from 22 to $52 \mathrm{KDa}$, were attributed to reduced copper ions and stabilized the nanoparticle suspension [28].

Fungi can also synthesize metallic oxide nanoparticles. The biogenic synthesis of copper oxides was performed using Penicillium aurantiogriseum, P. citrinum and P. waksmanii isolated from soil [29]. The authors investigated the effects of experimental parameters ( $\mathrm{pH}$ and salt concentration) on the size of biogenic nanoparticles. SEM indicated a spherical shape of the nanoparticles [29]. Another green synthesis of $\mathrm{Cu}_{2} \mathrm{O}$ used Tridax procumbens leaf extract [30]. The resulting $\mathrm{Cu}_{2} \mathrm{O}$ nanoparticles were coated with polyaniline by a chemical polymerization technique. Hexagonal and cubic nanoparticles with rough surfaces were observed by SEM. The antibacterial effect of the $\mathrm{Cu}_{2} \mathrm{O}$ nanoparticles was evaluated against E. coli. A $65 \%$ inhibition of bacterial growth was observed upon the incubation of E. coli with $20 \mu \mathrm{g} / \mathrm{cm}^{3}$ of nanoparticles. A $100 \%$ inhibition was found for $\mathrm{Cu}_{2} \mathrm{O}$ concentrations in the range of $50-60 \mu \mathrm{g} / \mathrm{cm}^{3}$ [30]. Sangeetha et al. [31] produced mono-dispersed, versatile and highly stable $\mathrm{CuO}$ nanoparticles from Aloe vera extract. This method is both ecofriendly and inexpensive, and it produced spherical $\mathrm{CuO}$ nanoparticles with a size range of $15-30 \mathrm{~nm}$ [31].

\subsection{Iron Oxide $\left(\mathrm{Fe}_{2} \mathrm{O}_{3}, \mathrm{Fe}_{3} \mathrm{O}_{4}\right)$ Magnetic Nanoparticles}

Magnetic iron oxide nanoparticles show potential in several biomedical applications, including drug delivery, hyperthermia and nuclear magnetic resonance imaging [2,32,33]. In addition to the classical 
chemical methods of synthesis, there is an increasing interest in the use of biogenic techniques to obtain iron oxide nanoparticles [4].

In the presence of anionic iron complexes, and under aerobic conditions, Actinobacter spp. yielded two new proteins that synthesize magnetite nanoparticles. The biotransformation of ferri-/ferrocyanide complexes into magnetite was dependent on the proteins secreted by this bacterium [34]. Incubating Actinobacter spp. with a ferricyanide/ferrocyanide mixture for 24 or $48 \mathrm{~h}$ resulted in quasi-spherical magnetite nanoparticles $(10-40 \mathrm{~nm})$ and cubic nanoparticles $(50-150 \mathrm{~nm})$, respectively. The nanoparticles were stable in aqueous solutions for several weeks because of the biomolecules secreted by the bacterium and were superparamagnetic at room temperature [34]. The mycelia of acidophillic fungi, Verticillium sp. and Fusarium oxysporum, extracellularly form magnetite when they are exposed to an aqueous solution of $\mathrm{K}_{3}\left[\mathrm{Fe}(\mathrm{CN})_{6}\right]$ and $\mathrm{K}_{4}\left[\mathrm{Fe}(\mathrm{CN})_{6}\right]$ [35].

Shewanella strain $\mathrm{HN}-41$, a dissimilatory iron-reducing bacterium, forms iron oxide, with formate, pyruvate or lactate as an electron donor, through the reduction of $\mathrm{Fe}(\mathrm{III})$-oxyhydroxide, akaganeite $(\beta-\mathrm{FeOOH})[36]$. DNA-binding protein from the starved cells of the bacterium Listeria innocua, LiDps, and its triple-mutant lacking the catalytic ferroxidase centre LiDps-tm produced nanomagnets at the interface between molecular clusters and traditional magnetic nanoparticles in the presence of a ferroxidase center [37]. Yaaghoobi et al. [38] reported the biogenic production of magnetic iron oxide nanoparticles $(\leq 104 \mathrm{~nm})$ from Acinetobacter radioresistens. The authors compared the toxicity of biogenic and commercial iron oxide nanoparticles on red blood cells by evaluating hemagglutination, hemolysis and morphological changes. Severe hemagglutination was observed for commercial nanoparticles in a concentration-dependent manner from a concentration of $50 \mu \mathrm{g} / \mathrm{mL}$. Toxic effects and morphological changes in the peripheral blood cells were not observed from bacterial synthesized magnetic iron oxide nanoparticles [38]. Biogenic ferrihydrite $\left(\mathrm{Fe}_{2} \mathrm{O}_{3} n \mathrm{H}_{2} \mathrm{O}\right)$ nanoparticles that were synthesized by the bacteria Klebsiella oxytoca demonstrated composites in which amorphous or crystalline nanomaterials were observed with organic molecules [39-41]. Dissimilatory Fe(III)-reducing bacteria, such as Geobacter metallireducens and Shewanella putrifaciens, produce magnetite (nanocrystals) as a by-product of their metabolism in a growth medium [42]. Byrne et al. [43] described the production of $\mathrm{Fe}_{3} \mathrm{O}_{4}$ nanoparticles by Geobacter sulphurreducens by modulating the total biomass used at the start of the synthesis. The authors observed that smaller particle sizes and narrower size distributions were achieved with higher concentrations of bacteria. This finding indicated that adjusting experimental parameters in the microbial synthesis of nanoparticles affects the physical, chemical and morphological properties of biogenic nanomaterials. Nanosized biogenic magnetite nanoparticles $(10.0 \pm 4.0 \mathrm{~nm}$ in diameter) were synthesized by the dissimilatory iron-reducing bacterium, Shewanella sp., for heterogeneous catalysis in ozonation [44]. Iron oxide nanoparticles were produced by tannins, a natural and non-toxic polyphenolic compound extracted from plants [45,46]. Herrera-Becerra et al. [45] described the biogenic synthesis of magnetic hematite $\left(\mathrm{Fe}_{2} \mathrm{O}_{3}\right)$ nanoparticles with a size less than $10 \mathrm{~nm}$ and $\mathrm{pH} 10$ using tannins. Phenolic compounds, acting as capping agents, improve stabilization of the colloidal suspension and avoid nanoparticle aggregation. 


\subsection{Antimony Oxide $\left(\mathrm{Sb}_{2} \mathrm{O}_{3}\right)$ Nanoparticles}

As an inorganic semiconductor compound, antimony (III) oxide $\left(\mathrm{Sb}_{2} \mathrm{O}_{3}\right)$ has several applications in technology and in chemical catalysis [47]. Jha et al. [48,49] reported the low-cost reproducible biosynthesis of $\mathrm{Sb}_{2} \mathrm{O}_{3}$ nanoparticles at room temperature in the presence of baker's yeast (S. cerevisiae). Different characterization techniques revealed the formation of $\mathrm{Sb}_{2} \mathrm{O}_{3}$ nanoparticles in a face-centered cubic unit cell structure, with an average size of 3-12 $\mathrm{nm}$ [48].

\subsection{Silica $\left(\mathrm{SiO}_{2}\right)$ Nanoparticles}

Silica nanoparticles are important nanomaterials in biomedical applications such as nanocarriers for drug delivery systems [50,51]. Silica nanoparticles are widely used in industry, biomedical engineering and cosmetics [52].

In the presence an aqueous solutions of $\mathrm{K}_{2} \mathrm{SiF}_{6}(\mathrm{pH} 3.1)$, mycelia of Fusarium oxysporum led to the formation of silica nanoparticles that ranged in diameter from 5 to $15 \mathrm{~nm}$ with an average size of $9.8 \pm 0.2 \mathrm{~nm}$ [53]. The authors demonstrated that the fungus Fusarium oxysporum secretes proteins that extracellularly hydrolyze $\mathrm{SiF}_{6}{ }^{2-}$, yielding silica nanoparticles at room temperature [53]. Actinobacter sp. cells were harvested and washed with water under sterile conditions and resuspended in an aqueous solution of $\mathrm{K}_{2} \mathrm{SiF}_{6}$. They formed quasi-spherical silicon/silica $\left(\mathrm{Si} / \mathrm{SiO}_{2}\right)$ nanoparticles with an average size of $10 \mathrm{~nm}$ [54]. The cytotoxicity of the $\mathrm{Si} / \mathrm{SiO}_{2}$ nanocomposites towards human skin cells was evaluated because silica nanoparticles are used in applications that require direct skin contact [54]. The results demonstrated that the particles are not toxic to human skin cells [54].

\subsection{Titanium Dioxide ( $\left.\mathrm{TiO}_{2}\right)$ Nanoparticles}

$\mathrm{TiO}_{2}$ nanoparticles have important environmental, technological and biomedical applications [51,55]. Jha and Prasad [56] reported the reproducible room temperature biosynthesis of $\mathrm{TiO}_{2}$ nanoparticles (10-70 in size) by Lactobacillus sp. that were obtained from yogurt and probiotic tablets. In the presence of suitable carbon and nitrogen sources, lactobacillus or yeast cells interact with a $\mathrm{TiO}(\mathrm{OH})_{2}$ solution to produce $\mathrm{TiO}_{2}$ nanoparticles $(8-35 \mathrm{~nm})$ with few aggregates [57]. Lactobacilli have a negative electrokinetic potential, which is suitable for the attraction of cations, a step that is required for the biosynthesis of metallic nanoparticles.

\subsection{Uraninite $\left(\mathrm{UO}_{2}\right)$ Nanoparticles}

Nanoparticles of $\mathrm{UO}_{2}$ are important for nuclear applications. The reduction of soluble uranium salts by microbial agents represents an important part of the geochemical cycle of this metal and highlights a mechanism for the bioremediation of uranium contamination [58,59]. Dissimilatory metal- and sulfate-reducing bacteria, such as Desulfovibrio desulfuricans, results in the precipitation of biogenic $\mathrm{UO}_{2}$ (bio- $\mathrm{UO}_{2}$ ) [58-60]. Biogenic uraninite was anaerobically produced by Shewanella oneidensis strain MR-1, at pH $6.3\left[\mathrm{UO}_{2}\left(\mathrm{CO}_{3}\right)_{2}{ }^{2-}\right]$ and $8.0\left[\mathrm{UO}_{2}\left(\mathrm{CO}_{3}\right)_{3}{ }^{4-}\right]$ [61]. Shewanella putrefaciens interacts with $\mathrm{U}(\mathrm{VI})$ reductases and biogenic $\mathrm{U}(\mathrm{IV})$ on the cell surface with uranium salt. Uraninite particles accumulate on extracellular polymeric substances [62]. The average particle size was $3 \mathrm{~nm}$, as determined by high-resolution transmission electron microscopy (HRTEM) and X-ray absorption 
spectroscopy. Scanning electron microscopy (SEM) analysis revealed that nanoparticles exhibit extracellular accumulation [62]. The synthesis of biogenic $\mathrm{UO}_{2}$ nanoparticles $(5-10 \mathrm{~nm})$ was mediated by $S$. putrefaciens cell suspensions growing aerobically, followed by the anaerobic addition of a uranyl-bearing solution $\left[\left(\mathrm{UO}_{2}{ }^{+2}\right)\right.$-PIPES, $\mathrm{NH}_{4} \mathrm{Cl}-$ lactate- $\left.\mathrm{KHCO}_{3}-\mathrm{K}_{2} \mathrm{HPO}_{4}\right]$ [63].

\subsection{Zinc Oxide (ZnO) Nanoparticles}

Prasad and Jha [64] reported mild conditions for the biosynthesis of $\mathrm{ZnO}$ nanoparticles (5-15 $\mathrm{nm}$ ) by the probiotic microbes Lactobacillus sporoge. The biogenic $\mathrm{ZnO}$ nanoparticles demonstrated the promising application of decontamination with corrosive and highly toxic hydrogen sulfide gas [64].

\subsection{Zirconia $\left(\mathrm{ZrO}_{2}\right)$ Nanoparticles}

Zirconia nanoparticles are used as an electro-optic, piezoelectric and dieletric material because of their physicochemical features [65]. They are also an efficient catalyst [66]. Zirconia nanoparticles (average size of $8 \mathrm{~nm}$ ) were biosynthesized at room temperature by challenging the fungus F. oxysporum with aqueous $\mathrm{ZrF}_{6}^{2-}$ anions [66]. Cationic proteins (molecular weight 24 to $28 \mathrm{kDa}$ ) were reported to perform the extracellular hydrolysis of metal anions to $\mathrm{ZrO}_{2}$ nanoparticles [66].

\subsection{Tin oxide $\left(\mathrm{SnO}_{2}\right)$ Nanoparticles}

$\mathrm{SnO}_{2}$ nanoparticles (average size of $3 \mathrm{~nm}$ ) were successfully synthesized through a novel biogenic synthesis method using Saraca indica flower extract as a reducing agent [67]. Biogenic $\mathrm{SnO}_{2}$ nanoparticles demonstrated antibacterial activity against $E$. coli and antioxidant properties, as assayed by scavenging the free radical of 2,2-diphenyl-1-picrylhydrazyl hydrate. These particles demonstrate promise in biomedical applications [67].

\section{Nanotoxicity of Metal Oxide Nanoparticles}

Although a wide range of biogenic metallic nanoparticles have been investigated, few papers have reported the toxicity of these nanoparticles. The literature discusses the synthesis and characterization of biogenically synthesized metal oxide nanoparticles. To develop applications using metal oxide nanoparticles that are synthesized either by biogenic or classical methods, a detailed investigation of the human and environmental toxicity of these nanoparticles is required. This section summarizes the toxicity of different metal oxide nanoparticles synthesized by biogenic and chemical/physical techniques. Because of the importance of metallic nanoparticles, the nanotoxicology of these materials should be further characterized.

\subsection{Bismuth Trioxide (Bi2 $\left.\mathrm{O}_{3}\right)$ Nanocrystals}

Bismuth trioxide is not toxic to human tissue [68]. However, its chemical synthesis is complex and requires extreme conditions. Ionic bismuth is reduced by sodium borohydride and is then oxidized at high temperatures [3]. Biogenic synthesis is an ecofriendly methodology that is widely acceptable. No reports have described the toxicity of $\mathrm{Bi}_{2} \mathrm{O}_{3}$ nanoparticles, which indicates the necessity of investigating this area of nanotoxicology. Zhu et al. [69] described the preparation of hybrid nanogels 
composed of $\mathrm{Bi}_{2} \mathrm{O}_{3}$ quantum dots incorporated into a nanogel of poly(vinyl alcohol) (PVA). The incubation of $\mathrm{Bi}_{2} \mathrm{O}_{3} @$ PVA hybrid nanogels for $24 \mathrm{~h}$ with mouse melanoma B16F10 cells resulted in the incorporation of the metallic nanoparticles into the perinuclear and cytoplasm of the cells. No morphological damage was observed. A cytotoxicity evaluation demonstrated that more than $96 \%$ of the B16F10 cells survived in concentrations of up to $200 \mu \mathrm{g} / \mathrm{mL}$ of the hybrid nanogels [69]. These results indicate that this hybrid nanomaterial may be used in biomedical applications such as optical surgery, fluorescence detection and imaging diagnosis with minimal cytotoxic effects. The cytotoxicity of bare $\mathrm{Bi}_{2} \mathrm{O}_{3}$ nanoparticles alone was not evaluated.

\subsection{Cobalt Oxide $\left(\mathrm{Co}_{3} \mathrm{O}_{4}\right)$ Nanocrystals}

$\mathrm{Co}_{3} \mathrm{O}_{4}$ nanoparticles, synthesized by thermal decomposition, exert oxidative stress on human lymphocytes, damage DNA, and cause inflammatory responses [70]. Oxidative stress is an important factor for toxicity and causes the induction of apoptosis. The authors assumed that $\mathrm{Co}^{2+}$ ions, when released from cobalt oxide nanoparticles, are the primary source of toxicity through the induction of TNF- $\alpha$-caspase-8-p38-caspase-3 in immune cells [70]. $\mathrm{Co}_{3} \mathrm{O}_{4}$ nanoparticles induced cytotoxicity, morphological transformation, and genotoxicity in Balb3T3 cells [71,72]. Co-nanoparticles induce genotoxic effects in human peripheral leukocytes [73]. All of these effects were most likely because of cobalt ion dissolution from the nanoparticles. Bare $\mathrm{Co}_{3} \mathrm{O}_{4}$ nanoparticles are toxic towards primary human immune cells and affect human health. Surface modification (e.g., protein corona) may open the gateway for the use of $\mathrm{Co}_{3} \mathrm{O}_{4}$ nanoparticles in different areas [70].

The toxicity of $\mathrm{Co}_{3} \mathrm{O}_{4}$ nanoparticles were demonstrated in BEAS-2B cells, which are a model of airway epithelium of normal lung tissues [74]. Low soluble cobalt oxide nanoparticles were readily internalized by human lung cells through endocytosis via a clathrin-dependent pathway. Several techniques demonstrated that incorporated $\mathrm{Co}_{3} \mathrm{O}_{4}$ nanoparticles are partially solubilized within cell lysosomes because of the low $\mathrm{pH}$. There, the toxic cobalt ions are released from the nanoparticles (Figure 2) [74]. The authors suggested that the cytotoxic effects of cell incubation with cobalt oxide nanoparticles can be attributed to the release of $\mathrm{Co}^{2+}$ within the lysosome and/or oxidative stress because of the direct effects of metallic cobalt nanoparticles [74]. The toxicity of $\mathrm{Co}_{3} \mathrm{O}_{4}$ nanoparticles and cobalt ions was assayed in human umbilical vein endothelial (ECV-305) and human liver carcinoma (HepG2) cell lines [75]. Although cobalt metal oxide nanoparticles led to time- and concentration-dependent cytotoxicity, free $\mathrm{Co}^{2+}$ ions were more toxic. The induction of reactive oxygen species (ROS) was observed from $\mathrm{Co}_{3} \mathrm{O}_{4}$ nanoparticles, rather than $\mathrm{Co}^{2+}$ ions. Cellular uptake experiments demonstrated that metallic nanoparticles were readily internalized in vesicles inside the cytoplasm [75].

A previous report suggested that commercial bare $\mathrm{Co}_{3} \mathrm{O}_{4}$ nanoparticles associated to ovalbumin, as a protein corona, stimulated low allergic antibody production and in vivo inflammation (at both the subcutaneous and intraperitoneal antigen administration sites). Lower in vitro toxicity was observed while stimulating both Th1 and Th2 in vivo antibody responses, which indicated that $\mathrm{Co}_{3} \mathrm{O}_{4}$ nanoparticles maybe used as a vaccine adjuvant [76]. This finding is important for biogenic $\mathrm{Co}_{3} \mathrm{O}_{4}$ nanoparticles because they are naturally capped with protein during the biogenic synthesis 
process. Studies that investigate the toxicity of biogenically synthesized cobalt oxide nanoparticles are necessary.

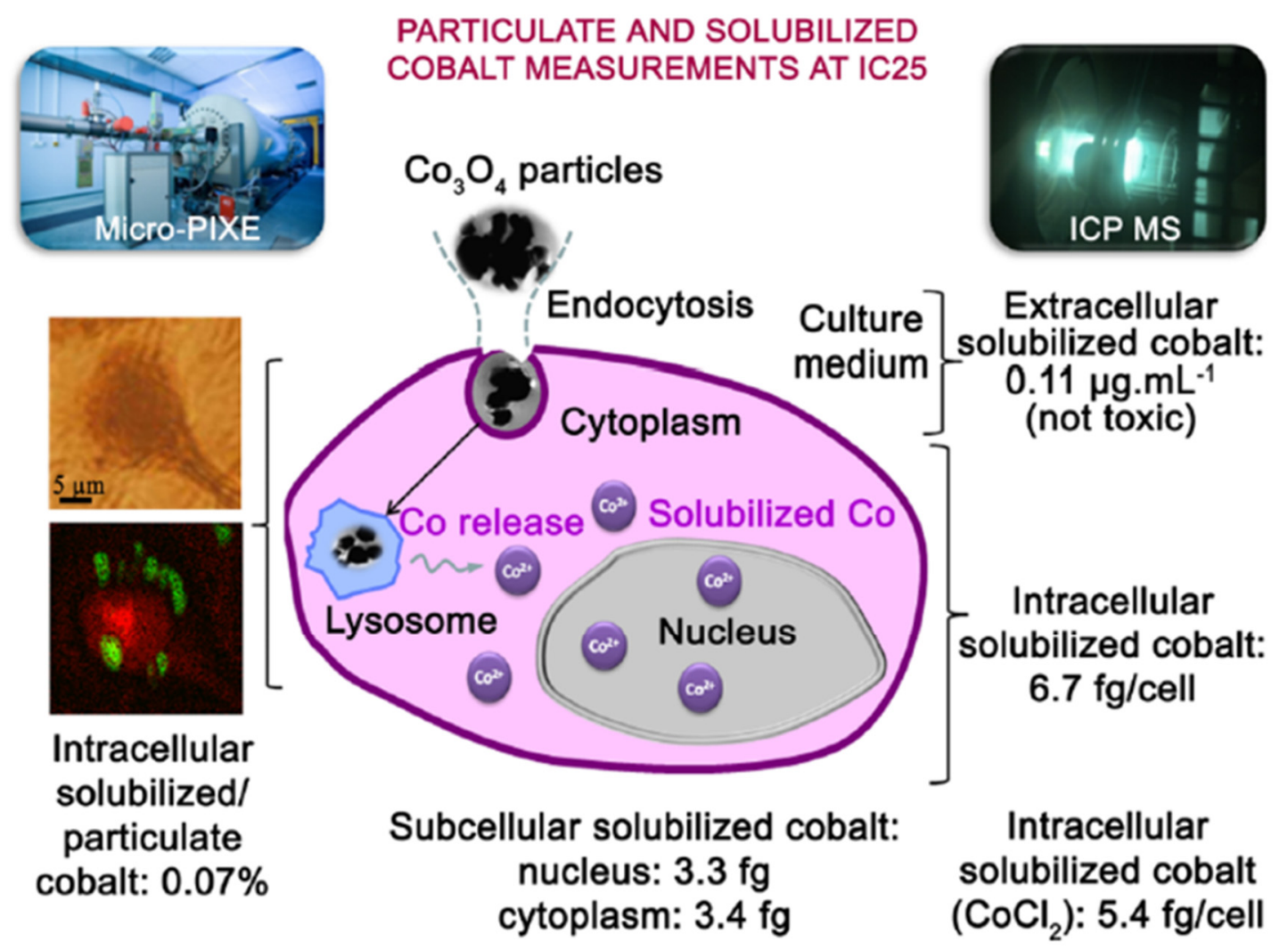

Figure 2. Schematic representation of the analytical methods and the quantification of cobalt internalized in cell compartments. $\mathrm{IC}_{25}$ : inhibiting concentration 25\%; Micro-PIXE: particle-induced X-ray emission; ICP-MS: inductively coupled plasma mass spectrometry. Reproduced from reference 74 with permission of the BioMed Central Ltd.

\subsection{Copper Oxide (CuO, $\left.\mathrm{Cu}_{2} \mathrm{O}\right)$ Nanoparticles}

The human lung epithelial cell line A549 was exposed to different nanomaterials including $\mathrm{CuO}$ [77]. Cytotoxicity was analyzed using trypan blue staining. DNA damage and oxidative lesions were determined using the comet assay, and the intracellular production of ROS was measured using the oxidation sensitive fluoroprobe 2',7'-dichlorofluorescin diacetate (DCFH-DA). CuO nanoparticles exerted a strong effect regarding cytotoxicity, DNA damage and ROS generation. The effects were not explained by soluble metal impurities [77]. $\mathrm{CuO}$ nanoparticles induced dose-dependent toxic effects at the biochemical, physiological and tissue levels in the blue mussel (Mytilus edulis) [78].

Microorganisms have been used to predict the potential nanotoxicity of metal oxide nanoparticles because of their functions in biogeochemical cycling in nature [79]. The antibacterial activity of copper oxide nanoparticles was reported. Usha et al. [27] demonstrated the biosynthesis of copper oxide nanoparticles by a Streptomyces sp. that interacted efficiently against E. coli, S. aureus, and Aspergillus niger after $48 \mathrm{~h}$ of incubation. Gopalakrishnan et al. [30] also reviewed the antibacterial nature of biologically synthesized cuprous oxide by plants against $E$. coli. 
Laha et al. [80] synthesized $\mathrm{CuO}$ nanoparticles $(30 \mathrm{~nm})$ by biophysical methods, and reported that $\mathrm{CuO}$ nanoparticles induced autophagy in a human breast cancer cell line (MCF7) in a time- and dose-dependent manner. Siddiqui et al. [81] reported that $\mathrm{CuO}$ nanoparticles (average size $22 \mathrm{~nm}$ ) induced cytotoxicity in human hepatocellular carcinoma (HepG2) cells in a dose-dependent manner $(2-50 \mathrm{mg} / \mathrm{mL})$ and reported that tumor suppressor gene p53 and apoptotic gene caspase-3 were upregulated upon exposure to $\mathrm{CuO}$ nanoparticles. Figure $3 \mathrm{~A}$ shows the field emission transmission electron microscopy (FETEM) image (inset with a higher magnification) of $\mathrm{CuO}$ nanoparticles. The nanoparticles are a spherical shape with smooth surfaces, and the inset of Figure $3 \mathrm{~A}$ revealed the crystalline nature of the $\mathrm{CuO}$ nanoparticles. Figure 3B reports the viability of HepG2 cells, as assayed by (3-(4,5-dimethylthiazol-2-yl)-2,5-diphenyltetrazolium bromide) (MTT), incubated for $24 \mathrm{~h}$ with $\mathrm{CuO}$ nanoparticles at different concentrations up to $50 \mu \mathrm{g} / \mathrm{mL}$. Cell viability was significantly reduced in a concentration-dependent manner $(83 \%, 69 \%, 52 \%, 34 \%$ and $28 \%)$ when the cells were exposed to varying concentrations of $\mathrm{CuO}$ nanoparticles $(2,5,10,25$ and $50 \mathrm{mg} / \mathrm{mL})$ [81].
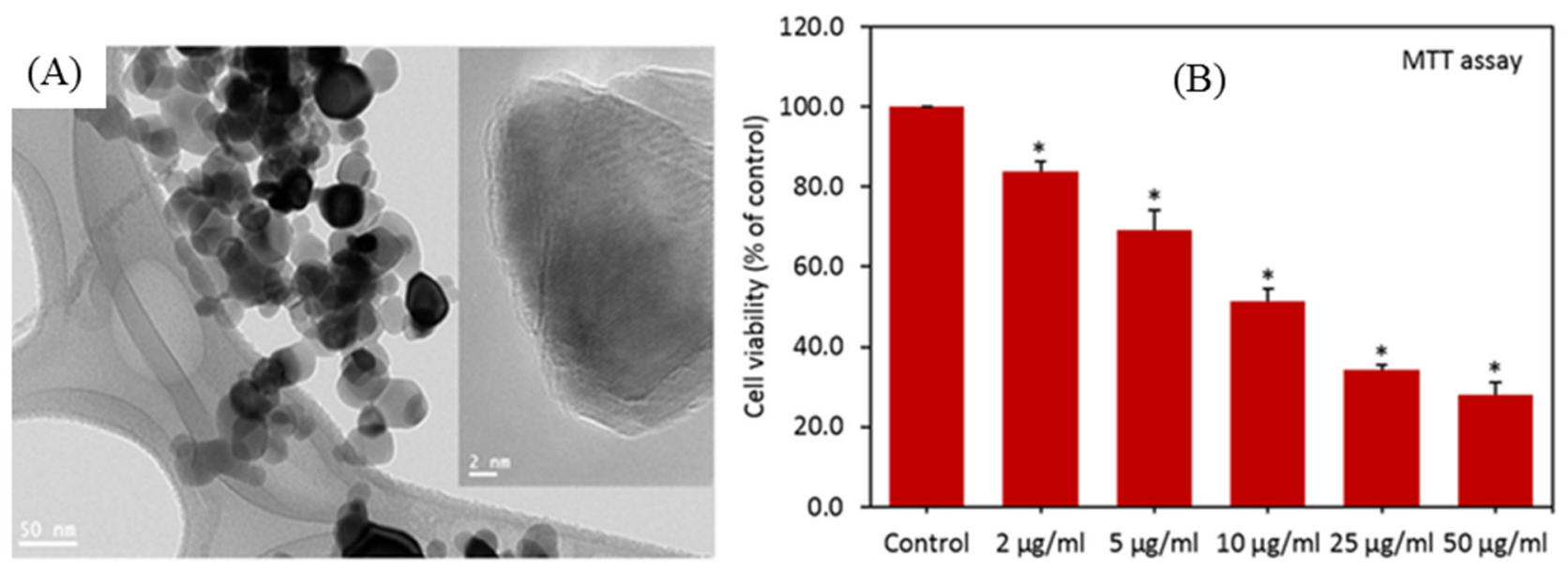

Figure 3. (A) Field emission transmission electron microscopy (FETEM) image (inset with higher magnification) of $\mathrm{CuO}$ nanoparticles. (B) Cytotoxicity of $\mathrm{CuO}$ nanoparticles in hepatocellular carcinoma cell line (HepG2) cells assayed by MTT. Incubation for $24 \mathrm{~h}$ at different nanoparticle concentrations. * Statistically significant difference compared with the controls $(p<0.05)$. Modified from reference 81 with permission of the PLoS One.

Sun et al. [82] exposed the A549, H1650 and CNE-2Z cell lines to chemically synthesized CuO nanoparticles and reported high toxicity on cell viability. The authors observed that the autophagic biomarker LC3-II significantly increased in A549 cells treated with $\mathrm{CuO}$ nanoparticles. The use of the autophagy inhibitors such as wortmannin and 3-methyladenin significantly improved cell survival [82]. These results indicate that the cytoxicity of $\mathrm{CuO}$ nanoparticles may involve the autophagic pathway in A549 cells. These results support the results reported by Laha et al. [80], in which $\mathrm{CuO}$ nanoparticles were incubated with cancer cells.

These papers refer to the cytotoxicity of chemically synthesized copper oxide nanoparticles. Biogenic copper oxide nanoparticles $(100-150 \mathrm{~nm})$ that were produced by Streptomyces sp. were applied to antimicrobial textiles. The cotton fabrics with copper nanoparticles displayed the maximum zone of mycostasis [27]. These results indicate the promising applications of copper oxide 
nanoparticles in clothing that reduces the transmission of infectious agents. The green synthesis of $\mathrm{CuO}$ nanoparticles from gum karya, a natural nontoxic hydrocolloid, demonstrated significant antibacterial actions against $E$. coli and $S$. aureus [83]. The smaller $(4.8 \pm 1.6 \mathrm{~nm}) \mathrm{CuO}$ nanoparticles yielded a maximum zone of inhibition compared to the larger size $(7.8 \pm 2.3 \mathrm{~nm})$ nanoparticles. The minimum bacterial concentrations for $\mathrm{CuO}$ nanoparticles, with an average size of $4.8 \mathrm{~nm}$, were $125 \pm 5.5 \mu \mathrm{g} / \mathrm{mL}$ for $E$. coli and $135 \pm 8.8 \mu \mathrm{g} / \mathrm{mL}$ for $S$. aureus [83]. CuO nanoparticles (5-45 $\mathrm{nm})$ produced using brown alga (Bifurcaria bifurcata) extract demonstrated antibacterial activity against Enterobacter aerogenes and Staphylococcus aureus [84]. Biogenic $\mathrm{CuO}$ nanoparticles (average size of $20 \mathrm{~nm}$ ), which were obtained by using Phyllanthus amarus leaf extract, showed antibacterial activity on multidrug resistance bacteria such as both Gram-positive (B. subtilis and $S$. aureus) and Gram-negative (E. coli and P. aeruginosa) bacteria [85]. Copper oxide nanoparticles (48 \pm 4 ), synthesized by using Tabernaemontana divaricate leaf extract, showed antimicrobial activity against urinary tract pathogens (the maximum inhibition was $50 \mu \mathrm{g} / \mathrm{mL}$ of nanoparticles against $E$. coli) [86].

These results demonstrated that chemically synthesized copper oxide nanoparticles are toxic to human cells. Some research has described the antibacterial actions of biogenically obtained copper oxide nanoparticles. The cytotoxicity of these biogenic nanoparticles in human cells should be evaluated.

\subsection{Iron Oxide $\left(\mathrm{Fe}_{2} \mathrm{O}_{3}, \mathrm{Fe}_{3} \mathrm{O}_{4}\right)$ Nanoparticles}

Iron oxide nanoparticles, such as magnetite $\left(\mathrm{Fe}_{3} \mathrm{O}_{4}\right)$ and hematite $\left(\mathrm{Fe}_{2} \mathrm{O}_{3}\right)$, have many important biomedical and industrial applications $[2,4]$. Nanotoxicology has become increasingly important. The toxicity of iron oxide nanoparticles has been evaluated through in vitro assays, although in vivo assays are becoming important [87].

In vitro studies of magnetosomes (membrane-enclosed inorganic crystals consisting of either the magnetic mineral magnetite $\left(\mathrm{Fe}_{3} \mathrm{O}_{4}\right)$ or greigite $\left(\mathrm{Fe}_{3} \mathrm{~S}_{4}\right)$ ) from Magnetospirillum gryphiswaldense with mouse fibroblast cells revealed the non-toxicity of the nanoparticles [88]. A review by Lang and Schuler [89] highlighted the important in vitro applications of bacterial magnetic nanoparticles (e.g., magnetic separation and procedures for labeling and immobilization of various biomolecules), and their environmental importance. These results demonstrated the biotechnological and nanotechnological potentials of bacterial magnetic nanoparticles [89]. Most papers have described the in vitro and in vivo toxicity of chemically and/or physically synthesized iron oxide nanoparticles $[32,87,90,91]$. The toxicity of iron oxide nanoparticles can be attributed to the ROS induction of oxidative stress [92], and it is dependent on the particle surface, size distribution, zeta potential, and the chemical nature of the surface coating [32,87].

An interesting study compared the cytotoxicity of synthetic and biogenic magnetite on L929 cells [93]. Co-precipitation was used to obtain the traditional iron oxide nanoparticles, and the biogenic nanoparticles were synthesized by magnetosomes isolated from MSR-1. The average particle size of the chemically synthesized magnetite nanoparticles was from 7 to $18 \mathrm{~nm}$, whereas a 10 to $60 \mathrm{~nm}$ size was observed for the magnetosomes. Both biogenic and chemically synthesized nanoparticles affected the metabolic activity of L929 cells in a concentration- and time-dependent manner (with a concentration range of $0.5-1.0 \mathrm{mg} / \mathrm{mL}$ and an incubation time of 24 to $72 \mathrm{~h}$ ). However, cell viability of 
L929 exposed to synthetic iron oxide nanoparticles was $85 \%$, whereas $90 \%$ was observed for biogenic magnetite; both exposures occurred at $1.0 \mathrm{mg} / \mathrm{mL}$ and with $72 \mathrm{~h}$ of incubation [93]. The authors assumed that the presence of a lipid membrane on the magnetosomes' surface increased the biocompatibility of the nanomaterial in comparison with chemically synthesized nanoparticles [93].

The toxicities of commercial and bacterial (Acinetobacter radioresistens) magnetic iron oxide nanoparticles on peripheral blood cells were evaluated by monitoring hemagglutination, hemolysis and morphological changes [38]. The authors observed lysis at low nanoparticle concentrations and severe hemagglutination in samples treated with commercial nanoparticles $(50 \mu \mathrm{g} / \mathrm{mL})$. Biogenic synthesized iron oxide nanoparticles did not induce morphological changes in peripheral blood cells [38]. These results indicate that biogenic iron oxide nanoparticles are less toxic than chemically generated iron oxide nanoparticles. However, further investigation is required.

\subsection{Antimony Oxide $\left(\mathrm{Sb}_{2} \mathrm{O}_{3}\right)$ Nanoparticles}

Antimony trioxide $\left(\mathrm{Sb}_{2} \mathrm{O}_{3}\right)$ is primarily used as a flame retardant in rubber, paper, pigments, adhesives, and plastics, among other materials. Antimony trioxide treatment was associated with the increased apoptosis associated with the induction of ROS and differentiation markers [94]. Apoptosis is increased upon the depletion of glutathione levels, and an increase of ROS in cells [94]. Bregoli et al. [95] reported the toxicity of $\mathrm{Sb}_{2} \mathrm{O}_{3}$ nanoparticles $(5 \mu \mathrm{g} / \mathrm{mL})$ on the proliferation of human hematopoietic progenitor cells. $\mathrm{Sb}_{2} \mathrm{O}_{3}$ nanoparticles were not toxic towards seven human cell lines of hematopoietic origin, which indicated that cell lines and primary cells (human hematopoietic progenitor cells) respond differently [95]. No studies have examined the toxicity of biogenically synthesized $\mathrm{Sb}_{2} \mathrm{O}_{3}$.

\subsection{Silica $\left(\mathrm{SiO}_{2}\right)$ Nanoparticles}

Several papers have described the toxicity of silica nanoparticles [50]. The nanotoxicity of amorphous $\mathrm{SiO}_{2}$ nanoparticles $(10 \mathrm{~nm})$ on human lung submucosal cells is associated with inflammation, release of ROS leading to apoptosis, and decreased cell survival [96]. The decreased viability of human airway epithelial cell line (Calu-3) exposed to $\mathrm{SiO}_{2}$ nanoparticles (concentrations up to $50 \mu \mathrm{g} / \mathrm{mL}$ ) for 2 to $24 \mathrm{~h}$ was reported in a concentration- and time-dependent manner. The nanotoxic effect of $\mathrm{SiO}_{2}$ nanoparticles was significantly attenuated by the flavonoid fisetin or catalase treatments, which indicated the oxidative stress mechanism for the toxicity of silica nanoparticles. Figure 4 shows the percentage of Calu-3 viability upon treatment with 25 or $50 \mu \mathrm{g} / \mathrm{mL}$ of $\mathrm{SiO}_{2}$ nanoparticles. In Figure 4A, Calu-3 cells were incubated with $\mathrm{SiO}_{2}$ nanoparticles in the absence or presence of fisetin $(10-80 \mu \mathrm{g} / \mathrm{mL})$ for $24 \mathrm{~h}$. Catalase also attenuated the decrease of cell viability caused by $\mathrm{SiO}_{2}$ nanoparticles (Figure 4B). The authors demonstrated that the toxic effects of $\mathrm{SiO}_{2}$ nanoparticles were because of the oxidative stress via ROS production [96].

The toxicity of commercially available $\mathrm{SiO}_{2}$ nanoparticles (10 and $300 \mathrm{~nm}$ ) was investigated in the RAW 264.7 mouse macrophage cell line [97]. The authors observed that $10 \mathrm{~nm} \mathrm{SiO}_{2}$ nanoparticles affected cell proliferation, morphology and cell cycle. A significant increase in TNF- $\alpha$ level was reported for RAW 264.7 cells exposed to $\mathrm{SiO}_{2}$ nanoparticles at a concentration of $0.01 \mathrm{~g} / \mathrm{L}$ for $24 \mathrm{~h}$. The $10 \mathrm{~nm}$ silica nanoparticles were internalized into the cells, whereas $300 \mathrm{~nm}$ silica nanoparticles 
were poorly internalized. Cells treated with smaller $\mathrm{SiO}_{2}$ nanoparticles greatly reduced phagocytosis, as monitored by the RAW 264.7 cells' uptake of E. coli. The bioaccumulation of small $\mathrm{SiO}_{2}$ nanoparticles within macrophages may suppress bacterial uptake and impair antibacterial activity [97].
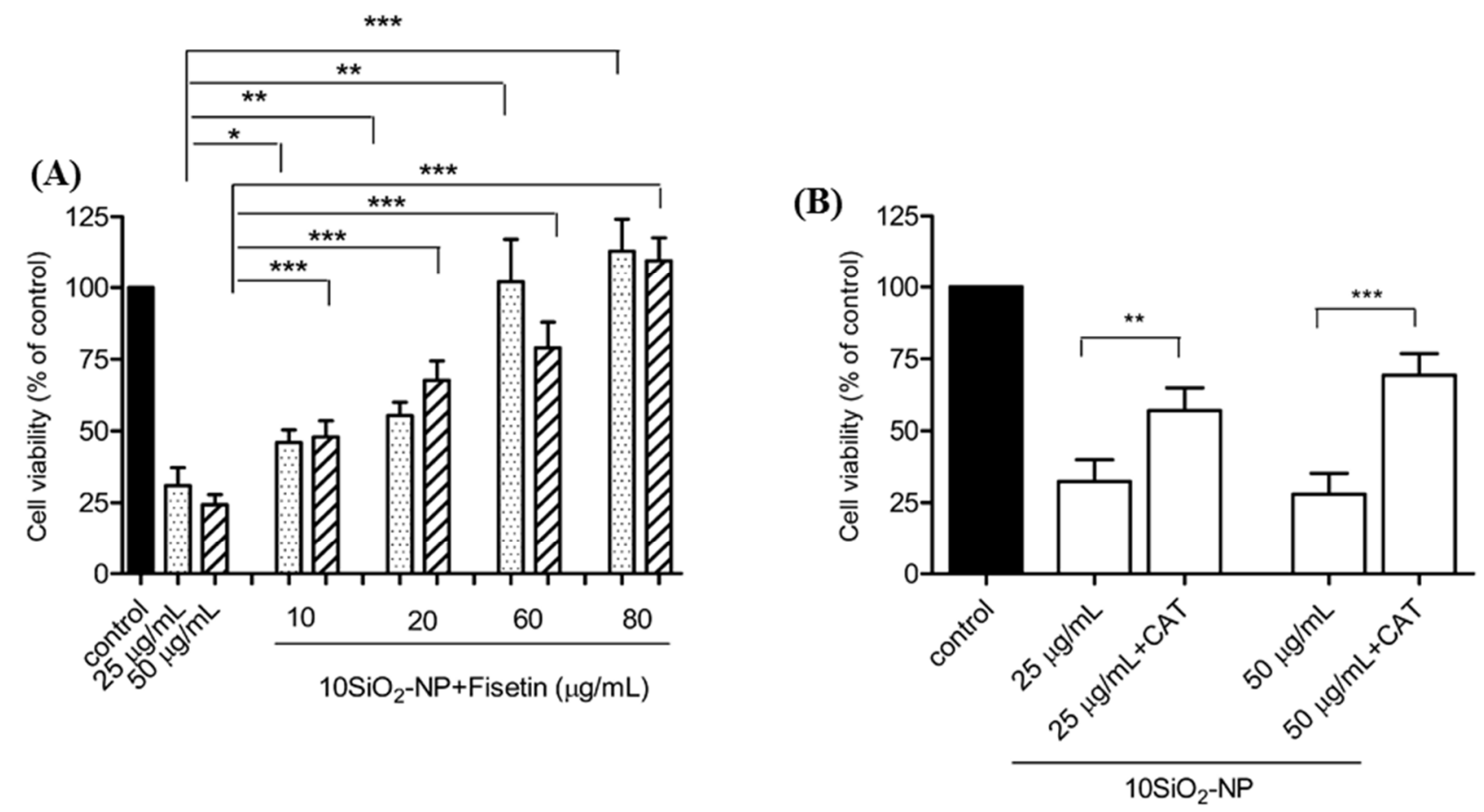

Figure 4. Cell viability of Calu-3 upon incubation with $\mathrm{SiO}_{2}$ nanoparticles. (A and $\mathbf{B}$ ) Prior incubation of cells with fisetin (A) and catalase (B) prevented the cell death induced by $\mathrm{SiO}_{2}$-nanoparticles $(25$ and $50 \mu \mathrm{g} / \mathrm{mL})$ on Calu-3. * $p<0.05, * * p<0.01$, and $* * * p<0.001, n=3-4$. Modified from reference 96 with permission of the American Chemical Society.

A recent in vivo study evaluated the toxic effects of suspensions of commercial silica nanoparticles (333 mg/kg/day, 10-15 nm) in Wister mice administered via oral gavage [98]. The authors reported significant changes in cholesterol, urea, total protein, LDL, HDL, aspartate aminotransferase activity and alkaline phosphatase activity. Histological evaluations revealed toxic effects on different tissues, such as lung, liver, testes and kidney [98]. Opposite results were reported by Kim et al. [99]. The in vivo toxicity of commercially obtained $\mathrm{SiO}_{2}$ nanoparticles $(20$ and $100 \mathrm{~nm})$ and average zeta potential of $-40 \mathrm{mV}$ were administered orally by gavage in Sprague-Dawley rats for 14 days. The doses ranged from 500 to $2000 \mathrm{mg} / \mathrm{kg}$. The results of a 90-day toxicity evaluation demonstrated no clinical or histopathological changes compared with the control group. Further studies are required to understand the in vivo toxicity of $\mathrm{SiO}_{2}$ nanoparticles.

In vitro studies reported the cytotoxicity of commercially available $\mathrm{SiO}_{2}$ nanoparticles on human mesenchymal stem cells for several concentrations $(25-400 \mu \mathrm{g} / \mathrm{mL})$ and incubation times (24-72 h) [100]. The metabolic stress of the cells was determined by alterations in the nuclear morphology, cytoplasm organization, and changes in gene expression [100].

Biogenically synthesized $\mathrm{Si} / \mathrm{SiO}_{2}$ nanocomposites (Actinobacter sp.) did not display cytotoxic effects to human epithelial cells (A431 cell line), which indicates that these biogenic nanoparticles may 
be useful in biomedical applications [54]. A431 cells were incubated with different concentrations of biogenically synthesized $\mathrm{Si} / \mathrm{SiO}_{2}$ nanocomposites $(50 \mu \mathrm{mol} / \mathrm{L}$ to $10 \mathrm{mmol} / \mathrm{L})$ for $3 \mathrm{~h}$. Further studies with longer incubation times (at least $24 \mathrm{~h}$ ) are necessary to better investigate the potent toxic effects of silica nanoparticles. The authors observed a toxic effect, measured as the percentage decrease of mitochondrial activity, for cells that were incubated with the higher concentrations of the $\mathrm{Si} / \mathrm{SiO}_{2}$ nanocomposite. The percentages of mitochondrial activity were $14.74 \%$ and $37.5 \%$ for $10 \mathrm{mmol} / \mathrm{L}$ and $5.0 \mathrm{mmol} / \mathrm{L}$ of the silica-based nanomaterial. Mitochondrial activity was more than $68 \%$ for cells incubated with 1.0 to $50 \mathrm{mmol} / \mathrm{L}$ of $\mathrm{Si} / \mathrm{SiO}_{2}$ nanocomposite. The concentration-dependent toxic effects of biogenic silica nanoparticles were also observed by the drastic changes in skin cell morphology that occurred upon treatment with 10 and $5.0 \mathrm{mmol} / \mathrm{L}$ of the nanomaterial [54].

\subsection{Titanium Dioxide ( $\left.\mathrm{TiO}_{2}\right)$ Nanoparticles}

Titanium dioxide nanoparticles $\left(\mathrm{TiO}_{2}\right)$ are one of the most widely used nanostructures in various areas. The study of the potential toxicity of this metal oxide nanoparticle has gained increasing attention [101]. Sheng et al. [102] showed demonstrated that 90 days of increased doses (2.5 to $10 \mathrm{mg} / \mathrm{kg}$ body weight) of intragastrically administered $\mathrm{TiO}_{2}$ nanoparticles resulted in spleen damage and immune dysfunction in mice. The authors also reported alterations in the expression of genes related to stress responses, cell proliferation, apoptosis, metabolic processes, and oxidative stress [102].

Regarding to biogenic nanoparticles, environmentally isolated Bacillus mycoides was used to synthesize anatase polymorphic $\mathrm{TiO}_{2}$ nanoparticles $(40-60 \mathrm{~nm})$ with spherical morphologies for efficient green solar cells [103]. The biogenic nanoparticles exhibited no toxicity on E. coli cultures [103]. An antibacterial effect against $E$. coli was reported for biogenically synthesized $\mathrm{TiO}_{2}$ nanoparticles (62-74 nm) with a spherical/oval shape obtained from the fungus Aspergillus flavus [104]. The minimum inhibitory concentration value was $40 \mu \mathrm{g} / \mathrm{mL}$ for $E$. coli treated with fungus-mediated synthesized $\mathrm{TiO}_{2}$ nanoparticles [104]. The antibacterial activity of biogenically synthesized $\mathrm{TiO}_{2}$ nanoparticles $(28-54 \mathrm{~nm})$ that were obtained from the bacteria Aeromonas hydrophila was reported for $S$. aureus and $S$. pyogenes [105]. Therefore, biogenically synthesized $\mathrm{TiO}_{2}$ nanoparticles can have contradictory antibacterial effects, depending on the biological reducing and capping agent that is employed during the biogenic synthesis processes. These results indicate that this phenomenon requires further investigation.

The biocompatibility of biogenically synthesized $\mathrm{TiO}_{2}$ nanoparticles was reported by Babitha et al. [106]. $\mathrm{TiO}_{2}$ nanoparticles were obtained by a metal-resistant bacterium isolated from coal fly ash effluent. The nanoparticles had an anatase phase, a spherical shape with a smooth surface and a size in the range of $15-80 \mathrm{~nm}$. No hemolysis or cell death of NIH/3T3 cell lines were reported when the cells were incubated with up to $100 \mu \mathrm{g} / \mathrm{mL}$ of $\mathrm{TiO}_{2}$ nanoparticles, which indicated the biocompatibility of the biogenic nanoparticles. In vivo wound healing studies on Wister rats revealed that biogenic $\mathrm{TiO}_{2}$ nanoparticles accelerated the tissue repair process. Complete wound closure was demonstrated for rats that were treated with collagen films containing $25 \mu \mathrm{g} / \mathrm{mL}$ of biogenic $\mathrm{TiO}_{2}$ nanoparticles. Wound closure occurred after 18 days of treatment for the control group (rats treated with only collagen film) [106]. 


\subsection{Uraninite $\left(\mathrm{UO}_{2}\right)$ Nanoparticles}

Uranium oxide and uranyl nitrate have different toxicities. Uranyl nitrate is soluble in water and moderately soluble in body fluids, and it is readily transported into the body organs or absorbed through the skin, which leads to bioaccumulation and toxicity. The kidney is the most damaged organ [107,108]. Uranium oxide is largely insoluble. Only small particles are deposited in the pulmonary region of the lung and retained for long periods, which leads to radiological consequences. Because $\mathrm{UO}_{2}$ can be soluble in aqueous $\mathrm{HCl}$, some ingested $\mathrm{UO}_{2}$ nanoparticles could be absorbed in stomach, resulting in toxic effects [107,108]. Inhalation of aerosol containing uranium particles was slow in in vivo experiments with rats (half-life of 141.5 days) [109].

Monleau et al. [110] demonstrated that the DNA strand breaks in the lungs of rats that occurred after acute and chronic exposures to depleted uranium by inhalation were the consequence of oxidative stress and the induction of pro inflammatory IL8 and TNF $\alpha$. These effects may be linked to the depleted uranium doses and independent of the solubility of uranium oxide [106]. The biotransformations of uranyl salts are an important way to avoid environment contamination, and the presence of protein capping on the surface of biogenically synthesized $\mathrm{UO}_{2}$ nanoparticles can avoid posterior metal solubilization [63]. Lee et al. [111] reported the biogenic synthesis of $\mathrm{UO}_{2}$ (uraninite) nanocrystals by the iron-reducing bacterium, Shewanella putrefaciens CN32, from uranium-rich solution. A recent review [112] discussed the importance of bioreduction processes in which bacteria enzymatically reduce aqueous U(VI) (toxic) to insoluble U(IV) (less toxic) coupled with the oxidation of an organic electron donor [112]. Therefore, microorganisms play a key role in the environmental decontamination of soluble $\mathrm{U}(\mathrm{VI})$ by its reduction to the poorly soluble mineral uraninite $\left(\mathrm{UO}_{2}\right)[58,59,62,112]$.

\subsection{Zinc Oxide (ZnO) Nanoparticles}

Aspergillus terreus culture filtrate was used for the extracellular biosynthesis of zinc oxide nanoparticles $(55-83 \mathrm{~nm})$. The biogenic zinc oxide nanoparticles demonstrated antifungal activity against selected fungal species (A. niger, A. fumigatus and A. aculeatus) [113]. $\mathrm{ZnO}_{2}$ nanoparticles were employed as antimicrobial agents and were incorporated into materials such as textiles and personal care items [114]. Green synthesized zinc nanoparticles (size 16-108 nm), using leaves of Parthenium hysterophorous, demonstrated enzymatic and microbial activity [115]. The physiological parameters, which were related to the growth of Arachis hypogea L. pot culture, increased from 30 to 60 days of sowing compared with the control group. Therefore, biogenic $\mathrm{ZnO}$ nanoparticles with microbial activity may have applications in agriculture, where zinc is one of the essential micronutrients that need to be supplied to the crop [115].

The antibacterial properties of green-synthesized $\mathrm{ZnO}$ nanoparticles were demonstrated against Gram-negative (Salmonella paratyphi, Escherichia coli, Vibrio cholerae) and Gram-positive (Staphylococcus aureus) bacteria using zone inhibition methods [116]. The biogenic ZnO nanoparticles, which had an average size of $30 \mathrm{~nm}$ and quasi-spherical shape, were obtained from the leaf extract of Solanum nigrum [116]. 
Concerning to the toxicity of biogenic $\mathrm{ZnO}$ nanoparticles, recently, Darroudi et al. [117] reported the cytotoxic effect of $\mathrm{ZnO}$ nanopowder obtained from gelatin. The nanoparticles $(1.5-100 \mu \mathrm{g} / \mathrm{mL})$ were toxic when incubated with neuro2A cells (a fast-growing mouse neuroblastoma cell line) for $24 \mathrm{~h}$. Cell viability was decreased in a dose-dependent manner when nanoparticles were administered at a concentration greater than $2 \mu \mathrm{g} / \mathrm{mL}$ [117]. In a similar study, Tabernaemontana divaricate leaf extract was employed to synthesize zinc oxide nanoparticles (average size $36 \mathrm{~nm}$ ) [86]. The biogenic nanoparticles showed potent cytotoxic effects against MCF-7 breast cancer cell lines, with an $\mathrm{IC}_{50}$ value of $30.65 \mu \mathrm{g} / \mathrm{mL}$ after $24 \mathrm{~h}$ of treatment [86]. The IC50 value for biogenic $\mathrm{ZnO}$ nanoparticles was lower than that of biogenic copper oxides that were synthesized by the identical plant extract [118]. $\mathrm{ZnO}$ nanoparticles can have antimicrobial and anticancer activities. However, the toxicity of these nanoparticles towards human cell lines must be investigated.

\subsection{Zirconia $\left(\mathrm{ZrO}_{2}\right)$ Nanoparticles}

Zirconium oxide nanoparticles have been used in several skin care products such as cosmetics, deodorants and topical ointments, and they have showed significant toxicity [119]. One important application of $\mathrm{ZrO}_{2}$ is in composites for dental technology [120]. Li et al. [121] investigated the effect and biocompatibility of $20 \mathrm{wt} \% \mathrm{ZrO}_{2}$ nanoparticles $(50-75 \mathrm{~nm})$ of white Portland cement [121]. The presence of $\mathrm{ZrO}_{2}$ nanoparticles enhanced the degree of hydration by $26 \%$ and displayed a positive effect on the in vitro biocompatibility of $\mathrm{MG} 63$ osteosarcoma cells [121]. Therefore, $\mathrm{ZrO}_{2}$ nanoparticles are considered an important material for cement dental restoratives by increasing the hydration rate without cytotoxic effects. However, further investigation is necessary to establish the influence of $\mathrm{ZrO}_{2}$ nanoparticles in other dentistry applications. $\mathrm{ZrO}_{2}$ nanoparticles are also important in orthopedic implants. The carcinogenicity and chronic toxicity of $\mathrm{ZrO}_{2}$ containing yttrium oxide was evaluated by implanting solid rods into the thigh muscle of C57BL/6N mice for 24 months. No evidence of toxic effects was observed [119,122]. $\mathrm{ZrO}_{2}$, acting on the bacterial strains of E. coli, $S$. aureus and fungal strain of $A$. niger, exhibited activity against only the E. coli [123]. There is no report that describes the toxicity of biogenically synthesized $\mathrm{ZrO}_{2}$ nanoparticles.

\subsection{Tin Oxide $\left(\mathrm{SnO}_{2}\right)$ Nanoparticles}

Biogenic tin oxide nanoparticles (spherical in shape with a size range of 2-4 $\mathrm{nm}$ ) were synthesized from the Saraca indica flower [67]. $\mathrm{SnO}_{2}$ nanoparticles exhibited antibacterial activity against the Gram-negative bacteria $E$. coli. The mechanism for the antibacterial activity of $\mathrm{SnO}_{2}$ nanoparticles may be the efficient reaction of the metal oxide nanoparticles with the cell wall, which leads to the inactivation of the bacteria. The antioxidant activity of $\mathrm{SnO}_{2}$ nanoparticles was demonstrated by scavenging the free radical of 2,2-diphenyl-1-picrylhydrazyl hydrate. Biogenic $\mathrm{SnO}_{2}$ nanoparticles are a promising antibacterial agent and an antioxidant for pharmaceutical applications [67].

Biogenic $\mathrm{SnO}_{2}$ nanoparticles (spherical in shape with an average size of $20 \mathrm{~nm}$ ) were obtained from the aqueous extract of the agricultural waste dried peel of a sugar apple (Annona squamosa) [124]. The cytotoxicity of biogenic $\mathrm{SnO}_{2}$ nanoparticles was evaluated against a hepatocellular carcinoma cell line (HepG2). $\mathrm{SnO}_{2}$ nanoparticles inhibited the cell proliferation in a dose- and time-dependent manner. The IC50 value was $148 \mu \mathrm{g} / \mathrm{mL}$. Increased concentrations of $\mathrm{SnO}_{2}$ nanoparticles altered the cell 
morphology [124]. The genotoxicity of $\mathrm{SnO}_{2}$ nanoparticles and immobilized amylase $\mathrm{SnO}_{2}$ nanoparticles were investigated [125]. The authors reported that $90 \%$ of enzyme activity was retained upon amylase immobilization on $\mathrm{SnO}_{2}$ nanoparticles, and no DNA damage was observed in lymphocytes for $\mathrm{SnO}_{2}$ and amylase- $\mathrm{SnO}_{2}$ nanoparticles [125]. These results indicate the biocompatibility of $\mathrm{SnO}_{2}$ nanoparticles.

\section{Relative Toxicity of Metal Oxide Nanoparticles}

Several studies have compared the toxicity of different metal oxide nanoparticles, but not biogenically synthesized nanoparticles. $\mathrm{CuO}$, followed by $\mathrm{ZnO}$, is reported to be the most toxic nanoparticle $\mathrm{TiO}_{2}$ is the least toxic nanoparticle.

Cho et al. [126] compared the in vivo acute lung inflammogenicity and in vitro cytoxicity of $\mathrm{CuO}$, $\mathrm{SiO}_{2}, \mathrm{ZnO}$, and $\mathrm{Co}_{3} \mathrm{O}_{4}$ nanoparticles. $\mathrm{CuO}$ and $\mathrm{ZnO}$ were the most toxic nanoparticles in both in vitro and in vivo assays. Figure 5 shows the cytotoxicity of A549 cells after exposure to different nanoparticles for $24 \mathrm{~h}$. Cell death was measured by trypan blue staining or lactate dehydrogenase (LDH) levels [126].

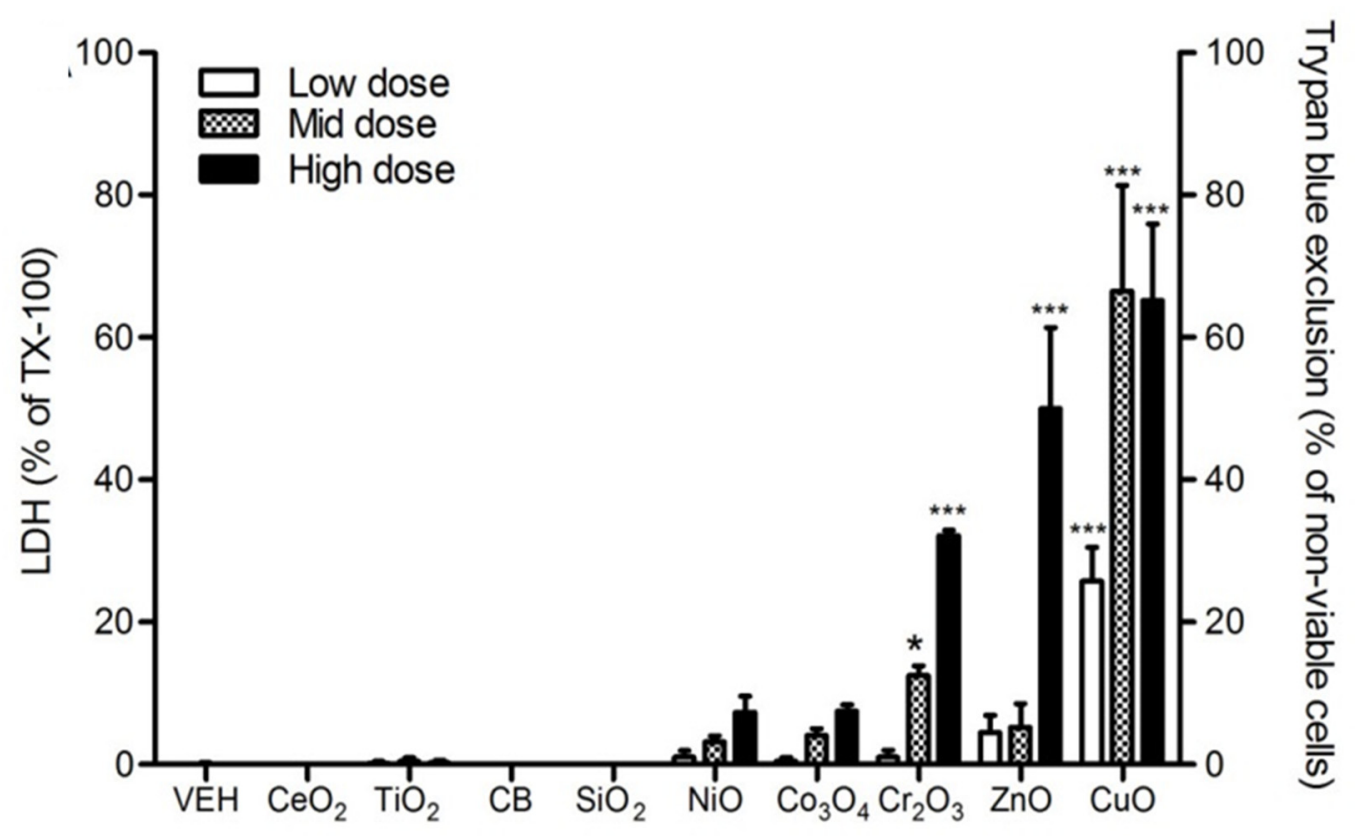

Figure 5. Cytotoxicity of several metal oxide nanoparticles on A549 cells after $24 \mathrm{~h}$ of nanoparticle treatment. Cytotoxicity was assayed by trypan blue exclusion for $\mathrm{ZnO}$ and $\mathrm{CuO}$ nanoparticles. Other particles were assayed by lactate dehydrogenase (LDH). The surface area doses were 30,100 , and $300 \mathrm{~cm}^{2} / \mathrm{mL}$ for all nanoparticles, with exception of $\mathrm{CuO}$ and $\mathrm{ZnO}$ nanoparticles, which were 3,10 , and $30 \mathrm{~cm}^{2} / \mathrm{mL}$. Values are mean $\pm \mathrm{SD}$ from a minimum of four independent experiments. Significance versus vehicle control $(\mathrm{VEH}): * p<0.05, * * * p<0.001 . \mathrm{CB}=$ Carbon back. Reproduced from reference 126 with permission of the BioMed Central Ltd.

Different cell lines, including A549, were incubated with metal oxide nanoparticles. $\mathrm{CuO}$ was the most toxic, ferric oxide and $\mathrm{TiO}_{2}$ nanoparticles exhibited slight toxicity and $\mathrm{SiO}_{2}$ nanoparticles 
resulted in mild toxicity [82]. Cell death induced by $\mathrm{CuO}$ nanoparticles was assigned to the autophagic pathway (cellular auto-digestion), mitochondria damage and oxidative stress [82]. The in vivo toxicity of $\mathrm{ZrO}_{2}$ and $\mathrm{SiO}_{2}$ nanoparticles was monitored upon oral administration to rats for 28 days in a dose of $1000 \mathrm{mg}$ of the nanoparticles/kg body weight/day [127]. $\mathrm{ZrO}_{2}$ and $\mathrm{SiO}_{2}$ nanoparticles did not cause significant systemic or local effects.

Concerning to microbial toxicity of metal oxide nanoparticles, Baek et al. [128] investigated the toxicity of $\mathrm{CuO}, \mathrm{ZnO}$ and $\mathrm{Sb}_{2} \mathrm{O}_{3}$ nanoparticles on $S$. aureus, E. coli and Bacillus subcillus. $\mathrm{CuO}$ nanoparticles were the most toxic because this material significantly reduced the colony forming units, followed by $\mathrm{ZnO}$ and $\mathrm{Sb}_{2} \mathrm{O}_{3}$ nanoparticles. The higher toxicity of $\mathrm{CuO}$ was demonstrated by Dasai et al. [129]. The authors compared the toxicity of different metal oxide nanoparticles to E. coli, both in the dark and under irradiation, in terms of the oxidative stress, amount of reduced glutathione, release of metal ions and lipid peroxidation. Under dark condition, the ranking of toxicity was $\mathrm{ZnO}>\mathrm{CuO}>\mathrm{Co}_{3} \mathrm{O}_{4}>\mathrm{TiO}_{2}$. Under light irradiation, the toxicity was $\mathrm{ZnO}>\mathrm{CuO}>\mathrm{TiO}_{2}>\mathrm{Co}_{3} \mathrm{O}_{4}$. In both cases, $\mathrm{ZnO}$ was the most toxic, followed by $\mathrm{CuO}$. The production of ROS was negligible in the dark and enhanced under light irradiation [129]. $\mathrm{ZnO}$ and $\mathrm{CuO}$ were reported to be the most toxic nanoparticles.

Recently, the ecotoxicity and cytotoxicity of several metal oxide nanoparticles were investigated using in vitro assays [130]. The proposed hazard ranking of the nanoparticles was $\mathrm{CuO}>\mathrm{ZnO}>\mathrm{Sb}_{2} \mathrm{O}_{3}$. The authors reported strong oxidative stress from the $\mathrm{CuO}$ nanoparticles [130]. Ko et al. [131] compared the toxic effects of different metal oxide nanoparticles on seed germination, gene mutation and bioluminescence activity of the Lactuca seed. The hazard ranking on seed germination was $\mathrm{CuO}>\mathrm{ZnO}>\mathrm{Co}_{3} \mathrm{O}_{4}, \mathrm{Fe}_{2} \mathrm{O}_{3}, \mathrm{TiO}_{2}$. Under bioluminescence, the ranking was $\mathrm{ZnO}>\mathrm{CuO}>\mathrm{Co}_{3} \mathrm{O}_{4}>$ $\mathrm{Fe}_{2} \mathrm{O}_{3}>\mathrm{TiO}_{2}[131]$.

\section{Final Remarks}

The applications of metal oxide nanoparticles have recently increased. These nanoparticles have been considered for diverse applications in biotechnology, catalysis, environmental bioremediation, optics, electronics, and cell energy and in the medical and pharmaceutic sciences (as a drug delivery system in the treatment and diagnosis of several diseases) [132,133]. The traditional chemical and physical methods used to synthesize metal oxide nanoparticles are expensive, time- and energyconsuming, tedious, toxic, and harmful to humans and the environment. The biogenic synthesis of metal oxide nanoparticles has emerged as an attractive alternative. Table 1 summarizes and compares the most important aspects of traditional versus green routes to synthesize metal oxide nanoparticles. The advantage and disadvantage of each route is highlighted, with the corresponding reference. Biogenic synthesis is straightforward and environmentally friendly [3-5,12-14]. Metal oxide nanoparticles can be obtained from different organisms such as plant extract, fungi, bacteria, algae, and actinomycetes [132]. This work reports the recent development in the use of green methods to obtain different types of metal oxide nanoparticles that can be used in a wide range of applications.

As shown in Table 1, traditional methods of synthesis require both strong and weak chemical reducing agents, and protective agents (sodium borohydride, sodium citrate and alcohols), which are mostly toxic, flammable, cannot be easily disposed off due to environmental issues. Moreover, 
traditional synthesis methods are carried out at elevated temperatures which generate a large amount of heat, and in some cases under inert atmosphere. Some traditional routes employed sophisticated instruments for experimentation. Although traditional methods yield nanoparticles with controlled size and dispersion (Table 1), these methods are considered not feasible. Hence, researchers are moving towards the biological synthesis for environmentally friendly synthesis of nanoparticles. As pointed out in Table 1, the main advantages of green methods to obtain the metal oxide nanoparticles are the simplicity, low cost, and no toxicity to the environment/humans. Moreover, different microflora such as bacteria, fungi, yeasts and plants have been successfully exploited as "nanofactories" for the synthesis of metal oxide nanoparticles. However, the main challenges related to green process to be overcome are: (i) limitations related to the scaling up the syntheses processes; (ii) the reproducibility of the biogenic processes needs to be improved; (iii) the mechanisms of nanoparticle formation are not completely elucidated; (iv) the control over nanoparticle size and distribution needs to be enhanced.

To use metal oxide nanoparticles (either synthesized by traditional or green methods), it is necessary to investigate their potential toxicity. The effect of metal oxide nanoparticles on humans and the environment is a topic that has received increasing interest and debate [129-131]. The reviewed literature indicates that the potential toxicities of these nanomaterials have not been completely addressed. Most research focuses on the toxicity of chemical or physical synthesized metal oxide nanoparticles. There are few reports that characterize the nanotoxicity of biogenic metal oxide nanoparticles. Based on published papers, the clearly determination of the similarities and differences, in terms of toxicity, of metal oxide nanoparticle obtained by traditional methods and by biogenic routes can be considered complex. This complexity is due to the different routes of nanoparticles synthesis, their different size, presence or absence of capping molecules, diverse kinds of toxicity evaluation tests, and lack of deeper studies of nanotoxicity of biogenic nanoparticles. Therefore, the potential toxic effects of biogenically obtained nanoparticles should be investigated further. The key points that must be addressed include the following: (i) In terms of the nanotoxicity of metal oxide nanoparticles, is there a difference between nanoparticles synthesized by traditional and by biogenic methods? (ii) What is the uptake of these nanoparticles by both humans and the environment? (iii) What is the mechanism of nanoparticle toxicity?

The literature suggests that nanotoxicity is related to (i) the possible release of (toxic) ions from metallic nanoparticles and (ii) the oxidative stress caused by the intrinsic characteristic of the nanoparticle (morphology, surface charge, size and chemical surface composition) [131]. Further studies are required to understand these mechanisms.

Finally, the toxicity of nanoparticles can differ depending on the experimental method employed [131]. Nanoparticles themselves can interfere with many tests, and it is often necessary to adapt the protocol to obtain reliable results [134,135]. A standardization of toxicity protocols, long-term study of nanoparticle toxicity and the fate of these nanomaterials in human tissue and in the environment need to be further investigated. 
Table 1. Comparison among main traditional versus green methods to synthesize metal oxide nanoparticles.

\begin{tabular}{|c|c|c|c|c|}
\hline \multicolumn{5}{|c|}{ Traditional Methods of Synthesis } \\
\hline Nanoparti & Route & Advantage & Disadvantage & Ref \\
\hline $\mathbf{B i}_{2} \mathbf{O}_{3}$ & $\begin{array}{l}\text { Hydrothermal process in assistance with the } \\
\text { post-heat treatment route }\end{array}$ & $\begin{array}{l}\text { Control of temperature impacts resulting } \\
\text { products }\end{array}$ & $\begin{array}{l}\text { Organic/toxic solvents and high } \\
\text { temperatures }\end{array}$ & {$[17]$} \\
\hline $\begin{array}{l}\mathrm{Bi}_{2} \mathrm{O}_{3} @ P V A \\
\text { nanogels }\end{array}$ & $\begin{array}{l}\mathrm{Bi}_{2} \mathrm{O}_{3} \text { quantum dots in the interior of a } \\
\text { nanogel of poly(vinyl alcohol) (PVA) }\end{array}$ & $\begin{array}{l}\text { The nanogels can adapt to a surrounding } \\
\text { fluids physiological temperature }\end{array}$ & $\begin{array}{l}\text { Require inert atmosphere and } \\
\text { irradiation with }{ }^{60} \mathrm{Co} \gamma \text {-ray source }\end{array}$ & [69] \\
\hline \multicolumn{5}{|c|}{ Green Methods of Synthesis } \\
\hline Nanoparticle & Route & Advantage & Disadvantage & Ref \\
\hline $\mathbf{B i}_{2} \mathbf{O}_{3}$ & $\begin{array}{l}\text { Plant pathogenic fungus - Fusarium } \\
\text { oxysporum }\end{array}$ & $\begin{array}{l}\text { Room temperature, nanoparticles are } \\
\text { stable in water }\end{array}$ & $\begin{array}{l}\text { Necessity to investigate the fungus } \\
\text { proteins on the surface of } \mathrm{Bi}_{2} \mathrm{O}_{3}\end{array}$ & [19] \\
\hline \multicolumn{5}{|c|}{ Traditional Methods of Synthesis } \\
\hline Nanoparticle & Route & Advantage & Disadvantage & Ref \\
\hline $\mathrm{Co}_{3} \mathrm{O}_{4}$ & Solvothermal route & Template-free approach & High temperature & [20] \\
\hline $\mathrm{Co}_{3} \mathrm{O}_{4}$ & $\begin{array}{l}\text { Thermal decomposition of molecular } \\
\text { precursors derived from salicylic acid and } \\
\text { cobalt (II) acetate or chloride }\end{array}$ & Template-free approach & High temperature & [21] \\
\hline $\begin{array}{l}\mathrm{Co}_{3} \mathrm{O}_{4} \\
\text { Nanoplates }\end{array}$ & $\begin{array}{l}\text { Solid-state crystal re-construction route by } \\
\text { conversion of hexagonal } \beta-\mathrm{Co}(\mathrm{OH})_{2} \\
\text { nanoplates }\end{array}$ & Template-free approach & Time consuming, high temperature & [22] \\
\hline $\mathrm{Co}_{3} \mathrm{O}_{4}$ & Thermal decomposition & Control over size and shape & $\begin{array}{l}\text { Toxicity to human cells and DNA } \\
\text { damage }\end{array}$ & [70] \\
\hline \multicolumn{5}{|c|}{ Green Methods of Synthesis } \\
\hline Nanoparticle & Route & Advantage & Disadvantage & Ref \\
\hline $\mathrm{Co}_{3} \mathrm{O}_{4}$ & Marine bacterium Brevibacterium casei & $\begin{array}{l}\text { The protein coating on nanoparticles } \\
\text { reduced agglomeration }\end{array}$ & $\begin{array}{l}\text { Challenges to be faced: better } \\
\text { control over size and crystallinity }\end{array}$ & [23] \\
\hline
\end{tabular}


Table 1. Cont

\begin{tabular}{|c|c|c|c|c|}
\hline & Traditional Methods of Synthesis & & & \\
\hline Nanoparticle & Route & Advantage & Disadvantage & Ref \\
\hline $\mathrm{CuO}, \mathrm{Cu}_{2} \mathrm{O}$ & Thermal decomposition & $\begin{array}{l}\text { Control over nanoparticle size and } \\
\text { distribution }\end{array}$ & Costly in energy consumption & [136] \\
\hline $\mathrm{CuO}$ & Electrospinning & Large scale production $\mathrm{CuO}$ & Time consumption & [137] \\
\hline \multicolumn{5}{|c|}{ Green Methods of Synthesis } \\
\hline Nanoparticle & Route & Advantage & Disadvantage & Ref \\
\hline $\mathrm{Cu}_{2} \mathrm{O}$ & Baker's yeast Saccharomyces cerevisiae & Room temperature no organic solvent & $\begin{array}{l}\text { Challenges to be faced: better } \\
\text { control over size and scaling up }\end{array}$ & {$[26]$} \\
\hline $\mathrm{CuO}, \mathrm{Cu}_{2} \mathrm{O}$ & Streptomyces sp. (Actinomycete biomass) & Environmentally friendly approach & $\begin{array}{l}\text { Difficulties to obtain monodisperse } \\
\text { nanoparticles and scaling up }\end{array}$ & {$[27]$} \\
\hline $\mathrm{CuO}, \mathrm{Cu}_{2} \mathrm{O}$ & Escherichia coli at aerobic condition & Neutral $\mathrm{pH}$ and room temperature & $\begin{array}{l}\text { Necessity to investigate the } \\
\text { bacterial proteins on the surface of } \\
\text { nanoparticles }\end{array}$ & {$[28]$} \\
\hline $\mathrm{CuO}, \mathrm{Cu}_{2} \mathrm{O}$ & $\begin{array}{l}\text { Penicillium aurantiogriseum, Penicillium } \\
\text { citrinum and Penicillium waksmanii isolated } \\
\text { from soil }\end{array}$ & Environmentally friendly approach & $\begin{array}{l}\text { Low rate of synthesis, difficulties to } \\
\text { obtain monodisperse nanoparticles. } \\
\text { Microbial cultivation need to be } \\
\text { improved }\end{array}$ & [29] \\
\hline $\mathrm{Cu}_{2} \mathrm{O}$ & Tridax procumbens leaf extract & Simple, cost effective & $\begin{array}{l}\text { Challenges to be faced: better } \\
\text { control over size and scaling up }\end{array}$ & {$[30]$} \\
\hline $\mathrm{CuO}$ & Aloe vera extract & Simple, cost effective & $\begin{array}{l}\text { Challenges to be faced: better } \\
\text { control over size and scaling up }\end{array}$ & {$[31]$} \\
\hline \multirow[t]{2}{*}{$\mathrm{CuO}, \mathrm{Cu}_{2} \mathrm{O}$} & White-rot fungus Stereum hirsutum & $\begin{array}{l}\text { Simple method, under neutral or basic } \\
\text { conditions }\end{array}$ & Scaling up and fungus cultivation & [138] \\
\hline & Traditional Methods of Synthesis & & & \\
\hline Nanoparticle & Route & Advantage & Disadvantage & Ref \\
\hline $\mathrm{Fe}_{3} \mathrm{O}_{4}$ & Co-precipitation & Relatively simple & Polydispersity $\mathrm{Fe}_{3} \mathrm{O}_{4}$ & [33] \\
\hline $\mathrm{Fe}_{3} \mathrm{O}_{4}$ & $\begin{array}{l}\text { Thermal decomposition of iron (III) } \\
\text { acetylacetonate }\left(\mathrm{Fe}(\mathrm{acac})_{3}\right)\end{array}$ & $\begin{array}{l}\text { Control of nanoparticle size and } \\
\text { dispersibility }\end{array}$ & $\begin{array}{l}\text { High temperature and inert } \\
\text { atmosphere }\end{array}$ & [139] \\
\hline
\end{tabular}


Table 1. Cont

\begin{tabular}{|c|c|c|c|c|}
\hline \multicolumn{5}{|c|}{ Green Methods of Synthesis } \\
\hline Nanoparticle & Route & Advantage & Disadvantage & Ref \\
\hline $\mathrm{Fe}_{3} \mathrm{O}_{4}$ & Bacterium Actinobacter spp & Aerobic conditions & $\begin{array}{l}\text { Limited scaling up, reaction time } \\
24-48 \mathrm{~h}\end{array}$ & {$[34]$} \\
\hline $\mathrm{Fe}_{3} \mathrm{O}_{4}$ & $\begin{array}{l}\text { Mycelia of acidophillic fungi, Verticillium } \\
\text { sp. and Fusarium oxysporum }\end{array}$ & Extracellular synthesis & $\begin{array}{l}\text { Limited scaling up, fungi } \\
\text { cultivation }\end{array}$ & {$[35]$} \\
\hline $\mathrm{Fe}_{2} \mathrm{O}_{3}, \mathrm{Fe}_{3} \mathrm{O}_{4}$ & Tannins from plants & $\begin{array}{l}\text { Natural, nontoxic, and biodegradable } \\
\text { polyphenolic compounds }\end{array}$ & Limited scaling up & {$[45]$} \\
\hline \multicolumn{5}{|c|}{ Traditional Methods of Synthesis } \\
\hline Nanoparticle & Route & Advantage & Disadvantage & Ref \\
\hline $\mathrm{Sb}_{2} \mathrm{O}_{3}$ & $\gamma$-ray radiation-oxidation route & Control over size and distribution & Expensive, special equipment & [140] \\
\hline $\mathrm{Sb}_{2} \mathrm{O}_{3}$ & Hydrothermal synthesis & Control over size and distribution & $\begin{array}{l}\text { External pressure, } \\
\text { high temperatures }\end{array}$ & [141] \\
\hline \multicolumn{5}{|c|}{ Green Methods of Synthesis } \\
\hline Nanoparticle & Route & Advantage & Disadvantage & Ref \\
\hline $\mathrm{Sb}_{2} \mathrm{O}_{3}$ & Baker's yeast (S. cerevisiae) & Low-cost, room temperature & Presence of nanoparticle aggregates & {$[48,49]$} \\
\hline \multicolumn{5}{|c|}{ Traditional Methods of Synthesis } \\
\hline Nanoparticle & Route & Advantage & Disadvantage & Ref \\
\hline $\mathrm{SiO}_{2}$ & $\begin{array}{l}\text { Micelle-templated protocol by varying the } \\
\text { silica source (tetra alkoxysilane with } \\
\text { different alkoxy group) and the type and } \\
\text { amounts of co-surfactant alcohols }\end{array}$ & Possibility to scaling up & $\begin{array}{l}\text { Relatively wide particle size } \\
\text { distribution, presence of } \\
\text { contaminants }\end{array}$ & [142] \\
\hline $\mathrm{SiO}_{2}$ & $\begin{array}{l}\text { Surfactant template method source of silica } \\
\text { tetra alkoxysilanes, and by varying the } \\
\text { amounts of co-surfactant alcohols }\end{array}$ & $\begin{array}{l}\text { Production of monodispersed spherical } \\
\text { morphologies of nanoparticles }\end{array}$ & Time and energy consuming & [143] \\
\hline
\end{tabular}


Table 1. Cont

\begin{tabular}{|c|c|c|c|c|}
\hline \multicolumn{5}{|c|}{ Green Methods of Synthesis } \\
\hline Nanoparticle & Route & Advantage & Disadvantage & Ref \\
\hline $\mathrm{SiO}_{2}$ & Fungus Fusarium oxysporum & Facile room temperature & $\begin{array}{l}\text { Necessity to investigated the fungus } \\
\text { secreted proteins involved in the } \\
\text { synthesis }\end{array}$ & [53] \\
\hline $\mathrm{SiO}_{2}$ & Bacterium Actinobacter $s p$ & $\begin{array}{l}\text { Particles were not cytotoxicity to human } \\
\text { skin cells }\end{array}$ & Relatively time consuming reaction & [54] \\
\hline \multicolumn{5}{|c|}{ Traditional Methods of Synthesis } \\
\hline Nanoparticle & Route & Advantage & Disadvantage & Ref \\
\hline $\mathrm{TiO}_{2}$ & $\begin{array}{l}\text { Hydrothermal growth using diethylamine as } \\
\text { a passivating agent }\end{array}$ & $\begin{array}{l}\text { Monodisperse nanoparticles with no phase } \\
\text { transformation during the synthesis }\end{array}$ & Time and energy consuming & {$[144]$} \\
\hline $\mathrm{TiO}_{2}$ & $\begin{array}{l}\text { Sol-gel method under different } \mathrm{pH} \\
\text { conditions }\end{array}$ & Control over nanoparticle size & $\begin{array}{l}\text { Toxic solvents, time and energy } \\
\text { consuming }\end{array}$ & {$[145]$} \\
\hline \multicolumn{5}{|c|}{ Green Methods of Synthesis } \\
\hline Nanoparticle & Route & Advantage & Disadvantage & Ref \\
\hline $\mathrm{TiO}_{2}$ & $\begin{array}{l}\text { Lactobacillus sp. (from yogurt and probiotic } \\
\text { tablets) or Sachharomyces cerevisae } \\
\text { (baker's yeast) }\end{array}$ & $\begin{array}{l}\text { Simple, room temperature and cost } \\
\text { effective }\end{array}$ & $\begin{array}{l}\text { Presence of few aggregates, } \\
\text { difficult to scaling up }\end{array}$ & {$[56,57]$} \\
\hline \multicolumn{5}{|c|}{ Traditional Methods of Synthesis } \\
\hline Nanoparticle & Route & Advantage & Disadvantage & Ref \\
\hline $\mathbf{U O}_{2}$ & $\begin{array}{l}\text { Radiolytic growth process in aqueous } \\
\text { solutions through electron beam irradiation }\end{array}$ & Control over size distribution & Expensive, special equipment & {$[146]$} \\
\hline $\mathbf{U O}_{2}$ & $\begin{array}{l}\text { Hydrothermal synthesis method using } \\
\text { hydrazine as a reducing agent }\end{array}$ & $\begin{array}{l}\text { Free of surfactant or template or organic } \\
\text { amines }\end{array}$ & Time and energy consuming & {$[147]$} \\
\hline \multicolumn{5}{|c|}{ Green Methods of Synthesis } \\
\hline Nanoparticle & Route & Advantage & Disadvantage & Ref \\
\hline $\mathbf{U O}_{2}$ & $\begin{array}{l}\text { Dissimilatory metal- and sulfate-reducing } \\
\text { bacteria Desulfovibrio desulfuricans }\end{array}$ & $\begin{array}{l}\text { Simple, room temperature and cost } \\
\text { effective }\end{array}$ & Microorganism growth & {$[58-60]$} \\
\hline
\end{tabular}


Table 1. Cont

\begin{tabular}{|c|c|c|c|c|}
\hline & Traditional Methods of Synthesis & & & \\
\hline Nanoparticle & Route & Advantage & Disadvantage & Ref \\
\hline $\mathrm{ZnO}$ & $\begin{array}{l}\text { Combustion process, in which } \\
\mathrm{Zn}\left(\mathrm{CH}_{3} \mathrm{COO}\right)_{2} \text { precursors migrated with the } \\
\text { aid of alcoholic fuel to the top of a burning } \\
\text { lampwick and the chemical reactions } \\
\text { occurred at the solvent-air interface of the } \\
\text { ignited lampwick }\end{array}$ & Relatively cost effective & $\begin{array}{l}\mathrm{ZnO} \text { exhibited a nonuniform size } \\
\text { and shape }\end{array}$ & [148] \\
\hline $\mathrm{ZnO}$ & Solvothermal synthesis & $\mathrm{ZnO}$ with good monodispersion in water & Organic toxic solvents & [149] \\
\hline $\mathrm{ZnO}$ & $\begin{array}{l}\text { Sol-gel processing technique based on } \\
\text { hydrolysis of zinc acetate in methanol } \\
\text { followed by supercritical drying in ethanol }\end{array}$ & Control over size and shape & Organic toxic solvents & {$[150]$} \\
\hline \multicolumn{5}{|c|}{ Green Methods of Synthesis } \\
\hline Nanoparticle & Route & Advantage & Disadvantage & Ref \\
\hline $\mathrm{ZnO}$ & Probiotic microbes Lactobacillus sporoge & Mild conditions and low-cost & Difficulties to scaling up & [64] \\
\hline \multicolumn{5}{|c|}{ Traditional Methods of Synthesis } \\
\hline Nanoparticle & Route & Advantage & Disadvantage & Ref \\
\hline $\mathrm{ZrO}_{2}$ & Sol-gel method & $\begin{array}{l}\text { Nanoparticles with high chemical and } \\
\text { structural homogeneity }\end{array}$ & Thermal treatment & [151] \\
\hline $\mathrm{ZrO}_{2}$ & $\begin{array}{l}\text { Thermal decomposition of the } \mathrm{Zr}(\mathrm{IV}) \\
\text { complex as in presence of methanol and } \\
\text { monoethylene glycol }\end{array}$ & Control over $\mathrm{ZrO}_{2}$ size and distribution & $\begin{array}{l}\text { Organic/toxic solvents, high } \\
\text { temperatures }\end{array}$ & [152] \\
\hline $\mathrm{ZrO}_{2}$ & $\begin{array}{l}\text { Thermal decomposition by zirconium oleate } \\
\text { complex in a high boiling organic solvent }\end{array}$ & $\begin{array}{l}\text { Production of oleophilic } \mathrm{ZrO}_{2} \text { as } \\
\text { nanofluilds }\end{array}$ & $\begin{array}{l}\text { Organic/toxic solvents, high } \\
\text { temperatures }\end{array}$ & [153] \\
\hline \multicolumn{5}{|c|}{ Green Methods of Synthesis } \\
\hline Nanoparticle & Route & Advantage & Disadvantage & Ref \\
\hline $\mathrm{ZrO}_{2}$ & Fungus Fusarium oxysporum & Extracellular hydrolysis, cost effect & $\begin{array}{l}\text { Fungus cultivation and scaling up } \\
\text { limitations }\end{array}$ & [66] \\
\hline
\end{tabular}


Table 1. Cont

\begin{tabular}{|c|c|c|c|c|}
\hline & Traditional Methods of Synthesis & & & \\
\hline Nanoparticle & Route & Advantage & Disadvantage & Ref \\
\hline $\mathrm{SnO}_{2}$ & $\begin{array}{l}\text { Chemical precipitation using glycine which } \\
\text { acts as a complexing agent and the } \\
\text { surfactant sodium dodecyl sulfate as a } \\
\text { stabilizing agent }\end{array}$ & Control over $\mathrm{SnO}_{2}$ size & $\begin{array}{l}\text { Necessity to use surfactant and high } \\
\text { temperature (up to } 600{ }^{\circ} \mathrm{C} \text { ) }\end{array}$ & [154] \\
\hline $\mathrm{SnO}_{2}$ & $\begin{array}{l}\text { Solvothermal synthesis of } \mathrm{SnO} \text { followed by } \\
\text { its oxidation to } \mathrm{SnO}_{2}\end{array}$ & Control over size and dispersion & $\begin{array}{l}\text { Multiple steps, organic/toxic } \\
\text { solvents }\end{array}$ & {$[155]$} \\
\hline $\mathrm{SnO}_{2}$ & $\begin{array}{l}\text { Reverse microemulsion method using } \\
\text { different water to surfactant ratio }\end{array}$ & $\begin{array}{l}\text { The size of the } \mathrm{SnO}_{2} \text { can be tcontrolled by } \\
\text { variation of water-to-surfactant ratio }\end{array}$ & $\begin{array}{l}\text { Multiple steps, high temperature } \\
\text { and necessity to sequential } \\
\text { calcinations to remove the } \\
\text { surfactant }\end{array}$ & {$[156]$} \\
\hline \multicolumn{5}{|c|}{ Green Methods of Synthesis } \\
\hline Nanoparticle & Route & Advantage & Disadvantage & Ref \\
\hline $\mathrm{SnO}_{2}$ & $\begin{array}{l}\text { Saraca indica flower extract as a reducing } \\
\text { agent }\end{array}$ & Simple, low cost & Scaling up & [67] \\
\hline \multicolumn{5}{|c|}{ T Traditional Methods of Synthesis } \\
\hline Nanoparti & Route & Advantage & Disadvantage & Ref \\
\hline $\mathrm{Bi}_{2} \mathbf{O}_{3}$ & $\begin{array}{l}\text { Hydrothermal process in assistance with the } \\
\text { post-heat treatment route }\end{array}$ & $\begin{array}{l}\text { Control of temperature impacts resulting } \\
\text { products }\end{array}$ & $\begin{array}{l}\text { Organic/toxic solvents and high } \\
\text { temperatures }\end{array}$ & [17] \\
\hline $\begin{array}{l}\mathrm{Bi}_{2} \mathrm{O}_{3} @ \mathrm{PVA} \\
\text { nanogels }\end{array}$ & $\begin{array}{l}\mathrm{Bi}_{2} \mathrm{O}_{3} \text { quantum dots in the interior of a } \\
\text { nanogel of poly(vinyl alcohol) (PVA) }\end{array}$ & $\begin{array}{l}\text { The nanogels can adapt to a surrounding } \\
\text { fluids physiological temperature }\end{array}$ & $\begin{array}{l}\text { Require inert atmosphere and } \\
\text { irradiation with }{ }^{60} \mathrm{Co} \gamma \text {-ray source }\end{array}$ & [69] \\
\hline \multicolumn{5}{|c|}{ Green Methods of Synthesis } \\
\hline Nanoparticle & Route & Advantage & Disadvantage & Ref \\
\hline $\mathbf{B i}_{2} \mathbf{O}_{3}$ & $\begin{array}{l}\text { Plant pathogenic fungus-Fusarium } \\
\text { oxysporum }\end{array}$ & $\begin{array}{l}\text { Room temperature, nanoparticles are } \\
\text { stable in water }\end{array}$ & $\begin{array}{l}\text { Necessity to investigate the fungus } \\
\text { proteins on the surface of } \mathrm{Bi}_{2} \mathrm{O}_{3}\end{array}$ & [19] \\
\hline
\end{tabular}


Table 1. Cont

\begin{tabular}{|c|c|c|c|c|}
\hline & Traditional Methods of Synthesis & & & \\
\hline Nanoparticle & Route & Advantage & Disadvantage & Ref \\
\hline $\mathrm{Co}_{3} \mathrm{O}_{4}$ & Solvothermal route & Template-free approach & High temperature & {$[20]$} \\
\hline $\mathrm{Co}_{3} \mathrm{O}_{4}$ & $\begin{array}{l}\text { Thermal decomposition of molecular } \\
\text { precursors derived from salicylic acid and } \\
\text { cobalt (II) acetate or chloride }\end{array}$ & Template-free approach & High temperature & {$[21]$} \\
\hline $\begin{array}{l}\mathrm{Co}_{3} \mathrm{O}_{4} \\
\text { Nanoplates }\end{array}$ & $\begin{array}{l}\text { Solid-state crystal re-construction route by } \\
\text { conversion of hexagonal } \beta-\mathrm{Co}(\mathrm{OH})_{2} \\
\text { nanoplates }\end{array}$ & Template-free approach & Time consuming, high temperature & {$[22]$} \\
\hline $\mathrm{Co}_{3} \mathrm{O}_{4}$ & Thermal decomposition & Control over size and shape & $\begin{array}{l}\text { Toxicity to human cells and DNA } \\
\text { damage }\end{array}$ & {$[70]$} \\
\hline \multicolumn{5}{|c|}{ Green Methods of Synthesis } \\
\hline Nanoparticle & Route & Advantage & Disadvantage & Ref \\
\hline \multirow[t]{2}{*}{$\mathrm{Co}_{3} \mathrm{O}_{4}$} & Marine bacterium Brevibacterium casei & $\begin{array}{l}\text { The protein coating on nanoparticles } \\
\text { reduced agglomeration }\end{array}$ & $\begin{array}{l}\text { Challenges to be faced: better } \\
\text { control over size and crystallinity }\end{array}$ & {$[23]$} \\
\hline & Traditional Methods of Synthesis & & & \\
\hline Nanoparticle & Route & Advantage & Disadvantage & Ref \\
\hline $\mathrm{CuO}, \mathrm{Cu}_{2} \mathrm{O}$ & Thermal decomposition & $\begin{array}{l}\text { Control over nanoparticle size and } \\
\text { distribution }\end{array}$ & Costly in energy consumption & [136] \\
\hline $\mathrm{CuO}$ & Electrospinning & Large scale production $\mathrm{CuO}$ & Time consumption & [137] \\
\hline
\end{tabular}


Table 1. Cont.

\begin{tabular}{|c|c|c|c|c|}
\hline \multicolumn{5}{|c|}{ Green Methods of Synthesis } \\
\hline Nanoparticle & Route & Advantage & Disadvantage & Ref \\
\hline $\mathrm{Cu}_{2} \mathrm{O}$ & Baker's yeast Saccharomyces cerevisiae & Room temperature no organic solvent & $\begin{array}{l}\text { Challenges to be faced: better } \\
\text { control over size and scaling up }\end{array}$ & {$[26]$} \\
\hline $\mathrm{CuO}, \mathrm{Cu}_{2} \mathrm{O}$ & Streptomyces sp. (Actinomycete biomass) & Environmentally friendly approach & $\begin{array}{l}\text { Difficulties to obtain monodisperse } \\
\text { nanoparticles and scaling up }\end{array}$ & [27] \\
\hline $\mathrm{CuO}, \mathrm{Cu}_{2} \mathrm{O}$ & Escherichia coli at aerobic condition & Neutral $\mathrm{pH}$ and room temperature & $\begin{array}{l}\text { Necessity to investigate the } \\
\text { bacterial proteins on the surface of } \\
\text { nanoparticles }\end{array}$ & {$[28]$} \\
\hline $\mathrm{CuO}, \mathrm{Cu}_{2} \mathrm{O}$ & $\begin{array}{l}\text { Penicillium aurantiogriseum, Penicillium } \\
\text { citrinum and Penicillium waksmanii isolated } \\
\text { from soil }\end{array}$ & Environmentally friendly approach & $\begin{array}{l}\text { Low rate of synthesis, difficulties to } \\
\text { obtain monodisperse nanoparticles. } \\
\text { Microbial cultivation need to be } \\
\text { improved }\end{array}$ & {$[29]$} \\
\hline $\mathrm{Cu}_{2} \mathrm{O}$ & Tridax procumbens leaf extract & Simple, cost effective & $\begin{array}{l}\text { Challenges to be faced: better } \\
\text { control over size and scaling up }\end{array}$ & {$[30]$} \\
\hline $\mathrm{CuO}$ & Aloe vera extract & Simple, cost effective & $\begin{array}{l}\text { Challenges to be faced: better } \\
\text { control over size and scaling up }\end{array}$ & [31] \\
\hline \multirow[t]{2}{*}{$\mathrm{CuO}, \mathrm{Cu}_{2} \mathrm{O}$} & White-rot fungus Stereum hirsutum & $\begin{array}{l}\text { Simple method, under neutral or basic } \\
\text { conditions }\end{array}$ & Scaling up and fungus cultivation & {$[138]$} \\
\hline & Traditional Methods of Synthesis & & & \\
\hline Nanoparticle & Route & Advantage & Disadvantage & Ref \\
\hline $\mathrm{Fe}_{3} \mathrm{O}_{4}$ & Co-precipitation & Relatively simple & Polydispersity $\mathrm{Fe}_{3} \mathrm{O}_{4}$ & {$[33]$} \\
\hline $\mathrm{Fe}_{3} \mathrm{O}_{4}$ & $\begin{array}{l}\text { Thermal decomposition of iron (III) } \\
\text { acetylacetonate }\left(\mathrm{Fe}(\mathrm{acac})_{3}\right)\end{array}$ & $\begin{array}{l}\text { Control of nanoparticle size and } \\
\text { dispersibility }\end{array}$ & $\begin{array}{l}\text { High temperature and inert } \\
\text { atmosphere }\end{array}$ & {$[139]$} \\
\hline
\end{tabular}


Table 1. Cont

\begin{tabular}{|c|c|c|c|c|}
\hline \multicolumn{5}{|c|}{ Green Methods of Synthesis } \\
\hline Nanoparticle & Route & Advantage & Disadvantage & Ref \\
\hline $\mathrm{Fe}_{3} \mathrm{O}_{4}$ & Bacterium Actinobacter spp. & Aerobic conditions & $\begin{array}{l}\text { Limited scaling up, reaction time } \\
24-48 \mathrm{~h}\end{array}$ & {$[34]$} \\
\hline $\mathrm{Fe}_{3} \mathrm{O}_{4}$ & $\begin{array}{l}\text { Mycelia of acidophillic fungi, Verticillium } \\
\text { sp. and Fusarium oxysporum }\end{array}$ & Extracellular synthesis & $\begin{array}{l}\text { Limited scaling up, fungi } \\
\text { cultivation }\end{array}$ & {$[35]$} \\
\hline $\mathrm{Fe}_{2} \mathrm{O}_{3}, \mathrm{Fe}_{3} \mathrm{O}_{4}$ & Tannins from plants & $\begin{array}{l}\text { Natural, nontoxic, and biodegradable } \\
\text { polyphenolic compounds }\end{array}$ & Limited scaling up & {$[45]$} \\
\hline \multicolumn{5}{|c|}{ Traditional Methods of Synthesis } \\
\hline Nanoparticle & Route & Advantage & Disadvantage & Ref \\
\hline $\mathrm{Sb}_{2} \mathrm{O}_{3}$ & $\gamma$-ray radiation-oxidation route & Control over size and distribution & Expensive, special equipment & {$[140]$} \\
\hline $\mathrm{Sb}_{2} \mathrm{O}_{3}$ & Hydrothermal synthesis & Control over size and distribution & $\begin{array}{l}\text { External pressure, } \\
\text { high temperatures }\end{array}$ & [141] \\
\hline \multicolumn{5}{|c|}{ Green Methods of Synthesis } \\
\hline Nanoparticle & Route & Advantage & Disadvantage & Ref \\
\hline $\mathrm{Sb}_{2} \mathrm{O}_{3}$ & Baker's yeast $(S$. cerevisiae $)$ & Low-cost, room temperature & Presence of nanoparticle aggregates & {$[48,49]$} \\
\hline \multicolumn{5}{|c|}{ Traditional Methods of Synthesis } \\
\hline Nanoparticle & Route & Advantage & Disadvantage & Ref \\
\hline $\mathrm{SiO}_{2}$ & $\begin{array}{l}\text { Micelle-templated protocol by varying the } \\
\text { silica source (tetra alkoxysilane with } \\
\text { different alkoxy group) and the type and } \\
\text { amounts of co-surfactant alcohols }\end{array}$ & Possibility to scaling up & $\begin{array}{l}\text { Relatively wide particle size } \\
\text { distribution, presence of } \\
\text { contaminants }\end{array}$ & [142] \\
\hline $\mathrm{SiO}_{2}$ & $\begin{array}{l}\text { Surfactant template method source of silica } \\
\text { tetra alkoxysilanes, and by varying the } \\
\text { amounts of co-surfactant alcohols }\end{array}$ & $\begin{array}{l}\text { Production of monodispersed spherical } \\
\text { morphologies of nanoparticles }\end{array}$ & Time and energy consuming & [143] \\
\hline
\end{tabular}


Table 1. Cont

\begin{tabular}{|c|c|c|c|c|}
\hline \multicolumn{5}{|c|}{ Green Methods of Synthesis } \\
\hline Nanoparticle & Route & Advantage & Disadvantage & Ref \\
\hline $\mathrm{SiO}_{2}$ & Fungus Fusarium oxysporum & Facile room temperature & $\begin{array}{l}\text { Necessity to investigated the fungus } \\
\text { secreted proteins involved in the } \\
\text { synthesis }\end{array}$ & [53] \\
\hline $\mathrm{SiO}_{2}$ & Bacterium Actinobacter sp. & $\begin{array}{l}\text { Particles were not cytotoxicity to human } \\
\text { skin cells }\end{array}$ & Relatively time consuming reaction & [54] \\
\hline \multicolumn{5}{|c|}{ Traditional Methods of Synthesis } \\
\hline Nanoparticle & Route & Advantage & Disadvantage & Ref \\
\hline $\mathrm{TiO}_{2}$ & $\begin{array}{l}\text { Hydrothermal growth using diethylamine as } \\
\text { a passivating agent }\end{array}$ & $\begin{array}{l}\text { Monodisperse nanoparticles with no phase } \\
\text { transformation during the synthesis }\end{array}$ & Time and energy consuming & {$[144]$} \\
\hline $\mathrm{TiO}_{2}$ & $\begin{array}{l}\text { Sol-gel method under different } \mathrm{pH} \\
\text { conditions }\end{array}$ & Control over nanoparticle size & $\begin{array}{l}\text { Toxic solvents, time and energy } \\
\text { consuming }\end{array}$ & {$[145]$} \\
\hline \multicolumn{5}{|c|}{ Green Methods of Synthesis } \\
\hline Nanoparticle & Route & Advantage & Disadvantage & Ref \\
\hline $\mathrm{TiO}_{2}$ & $\begin{array}{l}\text { Lactobacillus sp. (from yogurt and probiotic } \\
\text { tablets) or Sachharomyces cerevisae } \\
\text { (baker's yeast) }\end{array}$ & $\begin{array}{l}\text { Simple, room temperature and cost } \\
\text { effective }\end{array}$ & $\begin{array}{l}\text { Presence of few aggregates, } \\
\text { difficult to scaling up }\end{array}$ & {$[56,57]$} \\
\hline \multicolumn{5}{|c|}{ Traditional Methods of Synthesis } \\
\hline Nanoparticle & Route & Advantage & Disadvantage & Ref \\
\hline $\mathbf{U O}_{2}$ & $\begin{array}{l}\text { Radiolytic growth process in aqueous } \\
\text { solutions through electron beam irradiation }\end{array}$ & Control over size distribution & Expensive, special equipment & {$[146]$} \\
\hline $\mathbf{U O}_{2}$ & $\begin{array}{l}\text { Hydrothermal synthesis method using } \\
\text { hydrazine as a reducing agent }\end{array}$ & $\begin{array}{l}\text { Free of surfactant or template or organic } \\
\text { amines }\end{array}$ & Time and energy consuming & {$[147]$} \\
\hline \multicolumn{5}{|c|}{ Green Methods of Synthesis } \\
\hline Nanoparticle & Route & Advantage & Disadvantage & Ref \\
\hline $\mathbf{U O}_{2}$ & $\begin{array}{l}\text { Dissimilatory metal- and sulfate-reducing } \\
\text { bacteria Desulfovibrio desulfuricans }\end{array}$ & $\begin{array}{l}\text { Simple, room temperature and cost } \\
\text { effective }\end{array}$ & Microorganism growth & {$[58-60]$} \\
\hline
\end{tabular}


Table 1. Cont

\begin{tabular}{|c|c|c|c|c|}
\hline & Traditional Methods of Synthesis & & & \\
\hline Nanoparticle & Route & Advantage & Disadvantage & Ref \\
\hline $\mathrm{ZnO}$ & $\begin{array}{l}\text { Combustion process, in which } \\
\mathrm{Zn}\left(\mathrm{CH}_{3} \mathrm{COO}\right)_{2} \text { precursors migrated with the } \\
\text { aid of alcoholic fuel to the top of a burning } \\
\text { lampwick and the chemical reactions } \\
\text { occurred at the solvent-air interface of the } \\
\text { ignited lampwick }\end{array}$ & Relatively cost effective & $\begin{array}{l}\mathrm{ZnO} \text { exhibited a nonuniform size } \\
\text { and shape }\end{array}$ & [148] \\
\hline $\mathrm{ZnO}$ & Solvothermal synthesis & $\mathrm{ZnO}$ with good monodispersion in water & Organic toxic solvents & [149] \\
\hline $\mathrm{ZnO}$ & $\begin{array}{l}\text { Sol-gel processing technique based on } \\
\text { hydrolysis of zinc acetate in methanol } \\
\text { followed by supercritical drying in ethanol }\end{array}$ & Control over size and shape & Organic toxic solvents & {$[150]$} \\
\hline \multicolumn{5}{|c|}{ Green Methods of Synthesis } \\
\hline Nanoparticle & Route & Advantage & Disadvantage & Ref \\
\hline $\mathrm{ZnO}$ & Probiotic microbes Lactobacillus sporoge & Mild conditions and low-cost & Difficulties to scaling up & [64] \\
\hline \multicolumn{5}{|c|}{ Traditional Methods of Synthesis } \\
\hline Nanoparticle & Route & Advantage & Disadvantage & Ref \\
\hline $\mathrm{ZrO}_{2}$ & Sol-gel method & $\begin{array}{l}\text { Nanoparticles with high chemical and } \\
\text { structural homogeneity }\end{array}$ & Thermal treatment & [151] \\
\hline $\mathrm{ZrO}_{2}$ & $\begin{array}{l}\text { Thermal decomposition of the } \mathrm{Zr}(\mathrm{IV}) \\
\text { complex as in presence of methanol and } \\
\text { monoethylene glycol }\end{array}$ & Control over $\mathrm{ZrO}_{2}$ size and distribution & $\begin{array}{l}\text { Organic/toxic solvents, high } \\
\text { temperatures }\end{array}$ & [152] \\
\hline $\mathrm{ZrO}_{2}$ & $\begin{array}{l}\text { Thermal decomposition by zirconium oleate } \\
\text { complex in a high boiling organic solvent }\end{array}$ & $\begin{array}{l}\text { Production of oleophilic } \\
\mathrm{ZrO}_{2} \text { as nanofluilds }\end{array}$ & $\begin{array}{l}\text { Organic/toxic solvents, high } \\
\text { temperatures }\end{array}$ & [153] \\
\hline \multicolumn{5}{|c|}{ Green Methods of Synthesis } \\
\hline Nanoparticle & Route & Advantage & Disadvantage & Ref \\
\hline $\mathrm{ZrO}_{2}$ & Fungus Fusarium oxysporum & Extracellular hydrolysis, cost effect & $\begin{array}{l}\text { Fungus cultivation and scaling up } \\
\text { limitations }\end{array}$ & [66] \\
\hline
\end{tabular}


Table 1. Cont.

\begin{tabular}{|c|c|c|c|c|}
\hline & Traditional Methods of Synthesis & & & \\
\hline Nanoparticle & Route & Advantage & Disadvantage & Ref \\
\hline $\mathrm{SnO}_{2}$ & $\begin{array}{l}\text { Chemical precipitation using glycine which } \\
\text { acts as a complexing agent and the } \\
\text { surfactant sodium dodecyl sulfate as a } \\
\text { stabilizing agent }\end{array}$ & Control over $\mathrm{SnO}_{2}$ size & $\begin{array}{l}\text { Necessity to use surfactant and high } \\
\text { temperature (up to } 600{ }^{\circ} \mathrm{C} \text { ) }\end{array}$ & {$[154]$} \\
\hline $\mathrm{SnO}_{2}$ & $\begin{array}{l}\text { Solvothermal synthesis of } \mathrm{SnO} \text { followed by } \\
\text { its oxidation to } \mathrm{SnO}_{2}\end{array}$ & Control over size and dispersion & $\begin{array}{l}\text { Multiple steps, organic/toxic } \\
\text { solvents }\end{array}$ & {$[155]$} \\
\hline $\mathrm{SnO}_{2}$ & $\begin{array}{l}\text { Reverse microemulsion method using } \\
\text { different water to surfactant ratio }\end{array}$ & $\begin{array}{l}\text { The size of the } \mathrm{SnO}_{2} \text { can be controlled by } \\
\text { variation of water-to-surfactant ratio }\end{array}$ & $\begin{array}{l}\text { Multiple steps, high temperature } \\
\text { and necessity to sequential } \\
\text { calcinations to remove the } \\
\text { surfactant }\end{array}$ & {$[156]$} \\
\hline \multicolumn{5}{|c|}{ Green Methods of Synthesis } \\
\hline Nanoparticle & Route & Advantage & Disadvantage & Ref \\
\hline $\mathrm{SnO}_{2}$ & $\begin{array}{l}\text { Saraca indica flower extract as a reducing } \\
\text { agent }\end{array}$ & Simple, low cost & Scaling up & [67] \\
\hline
\end{tabular}




\section{Acknowledgments}

Support from FAPESP, CNPq, INOMAT (MCTI/CNPq), NanoBioss (MCTI), and the Brazilian Network on Nanotoxicology. The authors would like to acknowledge the Nature Publishing Group Language Editing for revising the English language usage of the manuscript.

\section{Conflicts of Interest}

The authors declare no conflict of interest.

\section{References}

1. Corr, S.A. Metal oxide nanoparticles. Nanoscience 2013, 1, 180-234.

2. Haddad, P.S.; Seabra, A.B. Biomedical applications of magnetic nanoparticles. In Iron Oxides: Structure, Properties and Applications; Martinez, A.I., Ed.; Nova Science Publishers, Inc.: New York, NY, USA, 2012; Volume 1, pp. 165-188.

3. Durán, N.; Seabra, A.B. Metallic oxide nanoparticles: State of the art in biogenic syntheses and their mechanisms. Appl. Microbiol. Biotechnol. 2012, 95, 275-288.

4. Seabra, A.B.; Haddad, P.S.; Duran N. Biogenic synthesis of nanostructured iron compounds: Applications and perspectives. IET Nanobiotechnol. 2013, 7, 90-99.

5. Rubilar, O.; Rai, M.; Tortella, G.; Diez, M.C.; Seabra, A.B.; Durán, N. Biogenic nanoparticles: Copper, copper oxides, copper sulfides, complex copper nanostructures and their applications. Biotechnol. Lett. 2013, 35, 1365-1375.

6. Rai, M.; Kon, K.; Ingle, A.; Durán, N.; Galdiero, S.; Galdiero M. Broad-spectrum Bioactivities of Silver Nanoparticles: The emerging trends and future prospects. Appl. Microbiol. Biotechnol. 2014, 98, 1951-1961.

7. Rai, M.; Birla, S.; Gupta, I.; Ingle, A.; Gade, A.; Abd-Elsalam, K.; Marcato, P.D.; Durán, N. Diversity in synthesis and bioactivity of inorganic nanoparticles: Progress and pitfalls. Nanotechnol. Rev. 2014, 3, 281-309.

8. Ingale, A.G.; Chaudhari, A.N. Biogenic synthesis of nanoparticles and potential applications: An eco-friendly approach. J. Nanomed. Nanotechol. 2013, 4, 1-7.

9. Galdiero, S.; Falanga, A.; Vitiello, M.; Cantisani, M.; Marra, V.; Galdiero, M. Silver nanoparticles as potential antiviral agents. Molecules 2011, 16, 8894-8918.

10. Durán, N.; Guterres, S.S.; Alves O.L. Nanotoxicology: Materials, Methodologies, and Assessments; Springer: New York, NY, USA, 2014; p. 412.

11. Ingle, I.P.; Durán, N.; Rai, M. Bioactivity, mechanism of action and cytotoxicity of copper-based nanoparticles: A review. Appl. Microbiol. Biotechnol. 2014, 98, 1001-1009.

12. De Lima, R.; Seabra, A.B.; Durán, N. Silver nanoparticles: A brief review of cytotoxicity and genotoxicity of chemically and biogenically synthesized nanoparticles. J. Appl. Toxicol. 2012, 32, 867-879.

13. Lima, R.; Feitosa, L.O.; Ballottin, D.; Marcato, P.D.; Tasic, L.; Durán, N. Cytotoxicity and genotoxicity of biogenic silver nanoparticles. J. Phys. Conf. Ser. 2013, 429, 012020. 
14. Schrofel, A.; Kratosova, G.; Safarik, I.; Safarikova, M.; Raska, I.; Shor, L.M. Applications of biosynthesized metallic nanoparticles-A review. Acta Biomater. 2014, 10, 4023-4042.

15. Tran, Q.H.; Nguyen, V.Q.; Le, A.-T. Silver nanoparticles: Synthesis, properties, toxicology, applications and perspectives. Adv. Nat. Sci. Nanosci. Nanotechnol. 2013, 4, 033001.

16. Seabra, AB.; Paula, A.J.; de Lima, R.; Alves, O.L.; Durán, N. Nanotoxicity of graphene and graphene oxide. Chem. Res. Toxicol. 2014, 27, 159-168.

17. Hou, J.; Yang, C.; Wang, Z.; Zhou, W.; Jiao, S.; Zhu, H. In situ synthesis of $\alpha-\beta$ phase heterojuntion on $\mathrm{Bi}_{2} \mathrm{O}_{3}$ nanowires with execptional visible-light photocatalytic performance. Appl. Catal. B Environ. 2013, 142-143, 504-511.

18. Li, Y.; Wu, S.; Huang, L.; Xu, H.; Zhang, R.; Qu, M.; Gao, Q.; Li, H. g-C $\mathrm{C}_{3} \mathrm{~N}_{4}$ modified $\mathrm{Bi}_{2} \mathrm{O}_{3}$ composites with enhanced visible-light photocatalytic activity. J. Phys. Chem. Solids 2015, 76, $112-119$.

19. Uddin, I.; Adhynthaya, S.; Syed, A.; Selvaraj, K.; Ahmad, A.; Poddar, P. Structure and microbial synthesis of sub-10 nm Bi $2 \mathrm{O}_{3}$ nanocrystals. J. Nanosci. Nanotechnol. 2008, 8, 3909-3913.

20. Cao, Y.; Yuan, F.; Yao, M.; Bang, J.H.; Lee, J.-H. A new synthetic route to hollow $\mathrm{Co}_{3} \mathrm{O}_{4}$ octahedra for supercapacitor applications. Cryst. Eng. Comm. 2014, 16, 826-833.

21. Hosny, N.M. Single crystalline $\mathrm{Co}_{3} \mathrm{O}_{4}$ : Synthesis and optical properties. Mater. Chem. Phys. 2014, 144, 247-251.

22. Su, D.; Xie, X.; Munroe, P.; Dou, S.; Wang, G. Mesoporous hexagonal $\mathrm{Co}_{3} \mathrm{O}_{4}$ for high performance lithium ion batteries. Sci. Rep. 2014, 4, doi:10.1038/srep06519.

23. Kumar, U.; Shete, A.; Harle, A.S.; Kasyutich, O.; Schwarzacher, W.; Pundle, A.; Poddar, P. Extracellular bacterial synthesis of proteinfunctionalized ferromagnetic $\mathrm{Co}_{3} \mathrm{O}_{4}$ nanocrystals and imaging of self-organization of bacterial cells under stress after exposure to metal ions. Chem. Mater. 2008, 20, 1484-1491.

24. Kanhed, P.; Birla, S.; Gaikwad, S.; Gade, A.; Seabra, A.B.; Rubilar, O.; Duran, N.; Rai, M. In vitro antifungal efficacy of copper nanoparticles against selected crop phatogenic fungi. Mater. Lett. 2014, 115, 13-17.

25. Hasan, S.S.; Singh, S.; Parikh, R.Y.; Dharne, M.S.; Patole, M.S.; Prasad, B.L.V.; Shouche, Y.S. Bacterial synthesis of copper/copper oxide nanoparticles. J. Nanosci. Nanotechnol. 2008, 8, 3191-3196.

26. Prasad, K.; Jha, A.K.; Prasad, K.; Kulkarni, A.R. Can microbes mediate nano-transformation? Indian J. Phys.2010, 84, 1355-1360.

27. Usha, R.; Prabu, E.; Palaniswamy, M.; Venil, C.K.; Rajendran, K.R. Synthesis of metal oxide nano particles by Streptomyces sp. for development of antimicrobial textiles. Global J. Biotechnol. Biochem. 2010, 5, 153-160.

28. Singh, A.V.; Patil, R.; Anand, A.; Milani, P.; Gade, W.N. Biological synthesis of copper oxide nano particles using Escherichia coli. Curr. Nanosci. 2010, 6, 365-369.

29. Honary, S.; Barabadi, H.; Gharaeifathabad, E.; Naghibi, F. Green synthesis of copper oxide nanoparticles using Penicillium aurantiogriseum, Penicillium citrinum and Penicillium waksmanii. Digest J. Nanomat. Biostruct. 2012, 7, 999-1005. 
30. Gopalakrishnan, K.; Ramesh, C.; Ragunathan, V.; Thamilselvan, M. Antibacterial activity of $\mathrm{Cu}_{2} \mathrm{O}$ nanoparticles on $E$. coli synthesized from Tridax procumbens leaf extract and surface coating with polyaniline. Digest J. Nanomat. Biostruct. 2012, 7, 833-839.

31. Sangeetha, G.; Rajeshwari, S.; Rajendran, V. Aloe barbadensis Miller mediated green synthesis of mono-disperse copper oxide nanoparticles: Optical properties. Spectrochim. Acta Part A 2012, 97, 1140-1144.

32. Seabra, A.B.; Pasquoto, T.; Ferrarini, A.C.F.; Cruz, M.; Haddad, P.S.; de Lima, R. Preparation, characterization, cytotoxicity and genotoxicity evaluations of thiolated- and $S$-nitrosated superparamagnetic iron oxide nanoparticles: Implications for cancer treatment. Chem. Res. Toxicol. 2014, 27, 1207-1218.

33. Molina, M.M.; Seabra, A.B.; de Oliveira, M.G.; Itri, R.; Haddad, P.S. Nitric oxide donor superparamagnetic iron oxide nanoparticles. Mat. Sci. Eng. C 2013, 33, 746-751.

34. Bharde, A.; Wani, A.; Shouche, Y.; Prasad, B.L.V.; Sastry, M. Bacterial aerobic synthesis of nanocrystalline magnetite. J. Am. Chem. Soc. 2005, 127, 9326-9327.

35. Bharde, A.; Rautaray, D.; Bansal, V.; Ahmad, A.; Sarkar, I.; Yusuf, S.M.; Sanyal, M.; Sastry, M. Extracellular biosynthesis of magnetite using fungi. Small 2006, 2, 135-141.

36. Lee, J.-H.; Roh, Y.; Kim, K.W.; Hur, H.-G. Organic acid-dependent iron mineral formation by a newly isolated iron reducing bacterium, Shewanella sp. HN-41. Geomicrobiol. J. 2007, 24, 31-34.

37. Ceci, P.; Chiancone, E.; Kasyutich, O.; Bellapadrona, G.; Castelli, L.; Fittipaldi, M.; Gatteschi, D.; Innocenti, C.; Sangregorio, C. Synthesis of iron oxide nanoparticles in Listeria innocua Dps (DNA-binding protein from starved cells): A study with the wild-type protein and a catalytic centre mutante. Chem. Eur. J., 2010, 16, 709-717.

38. Yaaghoobi, M.; Emtiazi, G.; Roghanian, R. A novel approach for aerobic construction of iron oxide nanoparticles by Acinetobacter radioresistens and their effects on red blood cells. Curr. Nanosci. 2012, 8, 286-291.

39. Raikher, Y.L.; Stepanov, V.I.; Stolyar, S.V.; Ladygina, V.P.; Balaev, D.A.; Ishchenko, L.A.; Balasoiu, M. Magnetic properties of biomineral nanoparticles produced by bacteria Klebsiella oxytoca. Phys. Solid State 2010, 52, 298-305.

40. Stolyar, S.V.; Bayukov, O.A.; Gurevich, Y.L.; Denisova, E.A.; Iskhakov, R.S.; Ladygina, V.P.; Puzyr, A.P.; Pustoshilov, P.P.; Bitekhtina, M.A. Iron-containing nanoparticles from microbial metabolismo. Inorg. Mater. 2006, 42, 763-768.

41. Balasoiu, M.; Stolyar, S.V.; Iskhakov, R.S.; Ishchenko, L.A.; Raikher, Y.L.; Kuklin, A.I.; Orelovich, O.L.; Kovalev, Y.S.; Kurkin, T.S.; Arzumanian, G.M. Hierarchical structure investigations of biogenic ferrihydrite samples. Rom. J. Phys. 2010, 55, 782-789.

42. Bazylinski, D.A.; Frankel, R.B.; Konhauser, K.O. Modes of biomineralization of magnetite by microbes. Geomicrobiol. J. 2007, 24, 456-475.

43. Byrne, J.M.; Telling, N.D.; Coker, V.S.; Pattrick, R.A.D.; van der Lann, G.; Arenholz, E.; Tuna, F.; Lloyd, J.R. Control of nanoparticle size, reactivity and magnetic properties during the bioproduction of magnetite by Geobacter sulfurreducens. Nanotechnology 2011, 22, 455709.

44. Jung, H.; Kim, J.W.; Choi, H.; Lee, J.-H.; Hur, H.-G. Synthesis of nanosized biogenic magnetite and comparison of its catalytic activity in ozonation. Appl. Catal. B 2008, 83, 208-213. 
45. Herrera-Becerra, R.; Rius, J.L.; Zorrilla, C. Tannin biosynthesis of iron oxide nanoparticles. Appl. Phys. A 2010, 100, 453-459.

46. Andjelkovic, M.; van Camp, J.; de Meulenaer, B.; Depaemelaere, G.; Socaciu, C.; Verloo, M.; Verhe, R. Iron-chelation properties of phenolic acids bearing catechol and galloyl groups. Food Chem. 2006, 98, 23-31.

47. Vukovic, M.; Brankovic, Z.; Poleti, D.; Recnik, A.; Brankovic, G. Novel simple methods for the synthesis of single-phase valentinite $\mathrm{Sb}_{2} \mathrm{O}_{3}$. J. Sol-Gel Sci. Technol. 2014, 72,527-533.

48. Jha, A.K.; Prasad, K.; Prasad, K. Biosynthesis of $\mathrm{Sb}_{2} \mathrm{O}_{3}$ nanoparticles: A low-cost green approach. Biotechnol. J. 2009, 4, 1582-1585.

49. Jha, A.K.; Prasad, K.; Prasad, K. A green low-cost biosynthesis of $\mathrm{Sb}_{2} \mathrm{O}_{3}$ nanoparticles. Biochem. Eng. J. 2009, 43, 303-306.

50. Zhu, Y.Y.; Liao, L.M. Applications of nanoparticles for anticancer drug delivery: A review. J. Nanosci. Nanotechnol. 2015, 7, 4753-4773.

51. Seabra, A.B.; Duran, N. Nitric oxide-releasing vehicles for biomedical applications. J. Mat. Chem. 2010, 20, 1664-1637.

52. Keller, A.A.; McFerran, S.; Lazareva, A.; Suh, S. Global life cycle releases of engineered nanomaterials. J. Nanopart Res. 2013, 15, 1692.

53. Bansal, V.; Rautaray, D.; Bharde, A.; Ahire, K.; Sanyal, A.; Ahmad, A.; Sastry, M. Fungus-mediated biosynthesis of silica and titania particles. J. Mater. Chem. 2005, 15, 2583-2589.

54. Singh, S.; Bhatta, U.M.; Satyam, P.V.; Dhawan, A.; Sastry, M.; Prasad, B.L.V. Bacterial synthesis of silicon/silica nanocomposites. J. Mater. Chem. 2008, 18, 2601-2606.

55. Goh, P.S.; Ng, B.C.; Lau, W.J.; Ismail, A.F. Inorganic nanomaterials in polymeric ultrafiltration membranes for water treatment. Sep. Purif. Rev. 2015, 44, 216-249.

56. Jha, A.K.; Prasad, K. Biosynthesis of metal and oxide nanoparticles using Lactobacilli from yoghurt and probiotic spore tablets. Biotechnol. J. 2010, 5, 285-291.

57. Jha, A.K.; Prasad, K.; Kulkarni, A.R. Synthesis of $\mathrm{TiO}_{2}$ nanoparticles using microorganisms. Colloids Surf. B Biointerf. 2009, 71, 226-229.

58. Lovley, D.R.; Phillips, E.J.P. Bioremediation of uranium contamination with enzymatic uranium reduction. Environ. Sci. Technol. 1992, 26, 2228-2234.

59. Lovley, D.; Phillips, E.J.P. Reduction of uranium by Desulfovibrio desulfuricans. Appl. Environ. Microbiol. 1992, 58, 850-856.

60. Tebo, B.M.; Obraztsova, A.Y. Sulfate-reducing bacterium grows with Cr(VI), U(VI), Mn(IV), and $\mathrm{Fe}(\mathrm{III})$ as electron acceptors. FEMS Microbiol. Lett. 1998, 16, 193-198.

61. Ulrich, K.U.; Ilton, E.S.; Veeramani, H.; Sharp, J.O.; Bernier-Latmani, R.; Schofield, E.J.; Bargar, J.R.; Giammar, D.E. Comparative dissolution kinetics of biogenic and chemogenic uraninite under oxidizing conditions in the presence of carbonate. Geochim. Cosmochim. Acta 2009, 73, 6065-6083.

62. Burgos, W.D.; McDonough, J.T.; Senko, J.M.; Zhang, G.X.; Dohnalkova, A.C.; Kelly, S.D.; Gorby, Y.; Kemner, K.M. Characterization of uraninite nanoparticles produced by Shewanella oneidensis MR-1. Geochim. Cosmochim. Acta 2008, 72, 4901-4915. 
63. Singer. D.M.; Farges, F.; Brown, G.E., Jr. Biogenic nanoparticulate $\mathrm{UO}_{2}$ : Synthesis, characterization, and factors affecting surfase reactivity. Geochim. Cosmochim. Acta 2009, 73, 3593-3611.

64. Prasad, K.; Jha, A.K. ZnO nanoparticles: synthesis and adsorption study. Natural Sci. 2009, 1, 129-135.

65. Somiya, S.; Yamamoto, N.; Yanagina, H. Science and Tecnology of Zirconia III (Advances in Ceramics); American Ceraminc Society: Westerville, OH, USA, 1988; Volumes 24A and 24B.

66. Bansal, V.; Rautaray, D.; Ahmad, A.; Sastry, M. Biosynthesis of zirconia nanoparticles using the fungus Fusarium oxysporum. J. Mater. Chem. 2004, 14, 3303-3305.

67. Vidhu, V.K.; Philip, D. Biogenic synthesis of $\mathrm{SnO}_{2}$ nanoparticles: Evaluation of antibacterial and antioxidant activities. Spectrochim. Acta Part A Mol. Biomol. Spec. 2015, 134, 372-379.

68. Bismuth Trioxide Toxicology. Available online: http://digitalfire.com/4sight/hazards/ceramic hazard_bismuth_trioxide_toxicology_352.html (accessed on 28 May 2015).

69. Zhu, H.; Li, Y.; Qiu, R.; Shi, L.; Wu, W.; Zhou, S. Responsive fluorescent $\mathrm{Bi}_{2} \mathrm{O}_{3} @ P V A$ hybrid nanogels for temperature-sensing, dual-modal imaging, and drug delivery. Biomaterials 2012, 33, 3058-3069.

70. Chattopadhyay, S.; Dash, S.K.; Tripathy, S.; Das, B.; Mandal, D.; Pramanik, P.; Roy, S. Toxicity of cobalt oxide nanoparticles to normal cells; an in vitro and in vivo study. Chem.-Biol. Inter. 2015, 226, 58-71.

71. Papis, E.; Gornati, R.; Prati, M.; Ponti, J.; Sabbioni, E.; Bernardini, G. Gene expression in nanotoxicology research: Analysis by differential display in BALB3T3 fibroblasts exposed to cobalt particles and ions. Toxicol. Lett. 2007, 107, 185-192.

72. Ponti, J.; Sabbioni, E.; Munaro, B.; Broggi, F.; Marmorato, P.; Franchini, F.; Colognato, R.; Rossi, F. Genotoxicity and morphological transformation induced by cobalt nanoparticles and cobalt chloride: An in vitro study in Balb/3T3 mouse fibroblasts. Mutagenesis 2009, 24, 438-445.

73. Colognato, R.; Bonelli, A.; Ponti, J.; Farina, M.; Bergamaschi, E.; Sabbioni, E.; Migliore, L. Comparative genotoxicity of cobalt nanoparticles and ions on human peripheral leukocytes in vitro. Mutagenesis 2008, 23, 377-382.

74. Ortega, R.; Bresson, C.; Darolles, C.; Gautiers, C.; Roudeau, S.; Perrin, L.; Janin, M.; Floriani, M.; Aloin, C.; Carmona, A.; et al. Low-solubility particles and a Trojan-horse type mechanism of toxicity: The case of cobalt oxide on human lung cells. Part. Fibre Toxicol. 2014, 11, doi:10.1186/1743-8977-11-14.

75. Papis, E.; Rossi, F.; Raspanti, M.; Dalle-Donne, I.; Colombo, G.; Milzani, A.; Bernardini, G.; Gornati, R. Engineered cobalt oxide nanoparticles readily enter cells. Toxicol. Lett. 2009, 189, 253-259.

76. Cho, W.-S.; Dart, K.; Nowakowska, D.J.; Zheng, X.; Donaldson, K.; Howie, S.E.M. Adjuvanticity and toxicity of cobalt oxide nanoparticles as an alternative vaccine adjuvant. Nanomedicine 2012, 7, 1495-1505.

77. Karlsson, H.L.; Cronholm, P.; Gustafsson, J.; Moller, L. Copper oxide nanoparticles are highly toxic: A comparison between metal oxide nanoparticles and carbon nanotubes. Chem. Res. Toxicol. 2008, 21, 1726-1732. 
78. Hu, W.; Culloty, S.; Darmody, G.; Lynch, S.; Davenport, J.; Ramirez-Garcia, S.; Dawson, K.A.; Lynch, I.; Blasco, J., Sheehan, D. Toxicity of copper oxide nanoparticles in the blue mussel, Mytilus edulis: A redox proteomic investigation. Chemosphere 2014, 108, 289-299.

79. Heinlaan, M.; Blinova, I.; Dubourguier, H.C.; Kahru, A. Toxicity of nanosized and bulk ZnO, $\mathrm{CuO}$ and $\mathrm{TiO}_{2}$ to bacteria Vibrio fischeri and crustaceans Daphnia magna and Thamnocephalus platyurus. Chemosphere 2008, 71, 1308-1316.

80. Laha, D.; Pramanik, A.; Maity, J.; Mukherjee, A.; Pramanik, P.; Laskar, A.; Karmakar, P. Interplay between autophagy and apoptosis mediated by copper oxide nanoparticles in human breast cancer cells MCF7. Biochim Biophys Acta 2014, 1840, 1-9.

81. Siddiqui, M.A.; Alhadlaq, H.A.; Ahmad, J.; Al-Khedhairy, A.A.; Musarrat, J.; Ahamed, M. Copper oxide nanoparticles induced mitochondria mediated apoptosis in human hepatocarcinoma cells. PLoS ONE 2013, 8, e69534.

82. Sun, T.; Yan, Y.; Zhao, Y.; Guo, F.; Jiang, C. Copper oxide nanoparticles induce autophagic cell death in A549 cells. PLOS ONE 2012, 7, e43442.

83. Padil, V.V.T.; Cerník, M. Green synthesis of copper oxide nanoparticles using gum karaya as a biotemplate and their antibacterial application. Inter. J. Nanomed. 2013, 8, 889-898.

84. Abboud, Y.; Saffaj, T.; Chagraoui, A.; Bouari, E.; Brouzi, K.; Tanane, O.; Ihssane, B. Biosynthesis, characterization and antimicrobial activity of copperoxide nanoparticles (CONPs) produced using brown alga extract (Bifurcaria bifurcata). Appl. Nanosci. 2014, 4, 571-576.

85. Acharyulu, N.P.S.; Dubey, R.S.; Swaminadham, V.; Kollu, P.; Kalyani, R.L.; Pammi, S.V.N. Green Synthesis of $\mathrm{CuO}$ Nanoparticles using Phyllanthus amarus Leaf Extract and their Antibacterial Activity against Multidrug Resistance Bacteria. Inter. J. Eng. Res. Technol. 2014, 3, 639-641.

86. Sivaraj, R.; Rahman, P.K.S.M.; Rajiv, P.; Venckatesh, H.A.S.R. Biogenic copper oxide nanoparticles synthesis using Tabernaemontana divaricate leaf extract and its antibacterial activity against urinary tract pathogen. Spectrochim. Acta Part A Mol. Biomol. Spec. 2014, 133, $178-181$.

87. Seabra, A.B.; Haddad, P.S. Cytotoxicity and Genotoxicity of Iron Oxides Nanoparticles. In Nanotoxicology: Materials, Methodologies, and Assessment; Durán, N., Guterres, S.S., Alves, O.L., Eds.; Springer: New York, NY, USA, 2014; Chapter 12, pp. 265-279.

88. Xiang, L.; Wei, J.; Jianbo, S.; Guili W, Feng G, Ying L. Purified and sterilized magnetosomes from Magnetospirillum gryphiswaldense MSR-1 were not toxic to mouse fibroblasts in vitro. Lett. Appl. Microbiol. 2007, 45, 75-81.

89. Lang, C., Schuler, D. Biogenic nanoparticles: Production, characterization, and application of bacterial magnetosomes. J. Phys. Condens. Matter. 2006, 18, S2815-S2828.

90. De Lima, R.; Oliveira, J.L.; Ludescher, A.; Molina, M.M.; Itri, R.; Seabra, A.B.; Haddad, P.S. Nitric oxide releasing iron oxide magnetic nanoparticles for biomedical applications: Cell viability, apoptosis and cell death evaluations. J. Phys. Conf. Ser. 2013, 429, 012034.

91. De Lima, R.; Oliveira, J.L.; Murakami, P.S.K.; Molina, M.M.; Itri, R.; Haddad, P.S.; Seabra, A.B. Iron oxide nanoparticles show no toxicity in the comet assay in lymphocytes: A promising vehicle as a nitric oxide releasing nanocarriers in biomedical applications. J. Phys. Conf. Ser. 2013, 429, 012021. 
92. Wu, H.; Yin, J.-J.; Wamer, W.G.; Zeng, M.; Lo, Y.M. Reactive oxygen species-related activities of nano-iron metal and nano-iron oxides. J. Food Drug Anal. 2014, 22, 86-94.

93. Han, L.; Li, S.; Yang, Y., Zhao, F.; Huang, J.; Chang, J. Comparison of magnetite nanocrystals formed by biomineralization and chemosynthesis. J. Mag. Mag. Mat. 2007, 313, 236-242.

94. Ross, G.; Harrison, A.P. The exposure to and health effects of antimony. Indian J. Occup. Environ. Med. 2009, 13, 3-10.

95. Bregoli, L.; Francesca, C.; Gambarelli, A.; Sighinolfi, G.; Gatti, A.M.; Santi, P.; Martelli, A.M.; Cocco, L. Toxicity of antimony trioxide nanoparticles on human hematopoietic progenitor cells and comparison to cell lines. Toxicology 2009, 262, 121-129.

96. McCarthy, J.; Inkielewicz-Stepniak, I.; Corbalan, J.J.; Radomski, M.M. Mechanisms of toxicity of amorphous silica nanoparticles on human Lung submucosal cells in vitro: Protective effects of Fisetin. Chem. Res. Toxicol. 2012, 25, 2227-2235.

97. Bancos, S.; Stevens, D.L.; Tyner, K.M. Effect of silica and gold nanoparticles on macrophage proliferation, activation markers, cytokine production, and phagocytosis in vitro. Int. J. Nanomed. 2015, 10, 183-206.

98. Hassankhani, R.; Esmaeillou, M.; Tehrani, A.A.; Nasirzadeh, K.; Khadir, F.; Maadi, H. In vivo toxicity of orally administrated silicon dioxide nanoparticles in healthy adult mice. Environ. Sci. Pollut. Res. 2015, 22, 1127-1132.

99. Kim, Y.-R.; Lee, S.-Y.; Lee, E.J.; Park, S.H.; Seong, N.; Seo, H.-S.; Shin, S.S.; Kim, S.J.; Meang, E.H.; Park, M.K.; et al. Toxicity of colloidal silica nanoparticles administered orally for 90 days in rats. Int. J. Nanomed. 2014, 9, 67-78.

100. Periasamy, V.S.; Athinarayanan, J.; Akbarsha, M.A.; Alshatwi, A.A. Silica nanoparticles induced metabolic stress through EGR1, CCND, and E2F1 genes in human mesenchymal stem cells. Appl. Biochem. Biotechnol. 2015, 175, 1181-1192.

101. Wang, J.; Fan, Y. Lung injury induced by $\mathrm{TiO}_{2}$ nanoparticles depends on their structural features: size, shape, crystal phases, and surface coating. Int. J. Mol. Sci. 2014, 15, 22258-22278.

102. Sheng, L.; Wang, L.; Sang, X.; Zhao, X.; Hong, J.; Cheng, S.; Yu, X.; Liu, D.; Xu, B.; $\mathrm{Hu}, \mathrm{R}$; et al. Nano-sized titanium dioxide-induced splenic toxicity: A biological pathway explored using microarray technology. J. Hazard. Mat. 2014, 278, 180-188.

103. Órdenes-Aenishanslins, N.A.; Saona, L.A.; Durán-Toro, V.M.; Monrás, J.P.; Bravo, D.M.; Pérez-Donoso, J.M. Use of titanium dioxide nanoparticles biosynthesized by Bacillus mycoides in quantum dot sensitized solar cells. Microb. Cell Fact. 2014, 13, 90.

104. Rajakumar, G.; Rahuman, A.; Roopan, S.M.; Khanna, V.G.; Elango, G.; Kamaraj, C.; Zahir, A.A.; Velayutham, K. Fungus-mediated biosynthesis and characterization of $\mathrm{TiO}_{2}$ nanoparticles and their activity against pathogenic bacteria. Spectrochim. Acta Part A 2012, 91, 23-29.

105. Jayaseelan, C.; Rahuman, A.; Roopan, S.M.; Kirthi, A.V.; Venkatesan, J.; Kim, S.K.; Iyappan, M.; Siva, C. Biological approach to synthesize $\mathrm{TiO}_{2}$ nanoparticles using Aeromonas hydrophila and its antibacterial activity. Spectrochim Acta Part A 2013, 107, 82-89.

106. Babitha, S.; Korrapati, P.S. Biosynthesis of titanium dioxide nanoparticles using a probiotic from coal fly ash effluent. Mater. Res. Bull. 2013, 48, 4738-4742. 
107. Documentation of the Threshold Limit Values and Biological Exposure Indices; 6th ed.; American Conference of Governmental Industrial Hygienists Inc: Cincinnati, OH, USA, 1991.

108. Craig, D.K. Chemical and radiological toxicity of uranium and its compounds. WSRC-TR-2001-00331. Available online: http://sti.srs.gov/fulltext/tr2001331/tr2001331.html (accessed on 28 May 2015).

109. Petitot, F.; Lestaevel, P.; Tourlonias, E.; Mazzucco, C.; Jacquinot, S.; Dhieux, B.; Delissen, O.; Tournier, B.B.; Gensdarmes, T.F.; Beaunier, P.; et al. Inhalation of uranium nanoparticles: Respiratory tract deposition and translocation to secondary target organs in rats. Toxicol. Lett. 2013, 217, 217-225.

110. Monleau, M.; de Meo, M.; Frelon, S.; Paquet, F.; Donnadieu-Claraz, M.; Duménil, G.; Chazel, V. Distribution and genotoxic effects after successive exposure to different uranium oxide particles inhaled by rats. Inhal. Toxicol. 2006, 18, 885-894.

111. Lee, S.Y.; Baik, M.H.; Choi, J.W. Biogenic formation and growth of uraninite $\left(\mathrm{UO}_{2}\right)$. Environ. Sci. Technol. 2010, 44, 8409-8414.

112. Newsome, L.; Morris, K.; Jonathan, R.; Lloyd, J.R. The biogeochemistry and bioremediation of uranium and other priority radionuclides. Chem. Geol. 2014, 363, 164-184.

113. Baskar, G.; Chandhuru, J.; Fahad, K.S.; Praveen, A.S. Mycological synthesis, characterization and antifungal activity of zinc oxide nanoparticles. Asian J. Pharm. Tech. 2013, 3, 142-146.

114. AbdElhady, M.M. Preparation and characterization of chitosan/zinc oxide nanoparticles for imparting antimicrobial and UV protection to cotton fabric. Int. J. Carbohy. Chem. 2012, 840591 .

115. Sindhura, K.S.; Prasad, T.N.V.K.V.; Selvam, P.P.; Hussain, O.M. Synthesis, characterization and evaluation of effect of phytogenic zinc nanoparticles on soil exo-enzymes. Appl. Nanosci. 2014, 4, 819-827.

116. Ramesh, M.; Anbuvannan, M.; Viruthagiri, G. Green synthesis of ZnO nanoparticles using Solanum nigrum leaf extract and their antibacterial activity. Spectrochim. Acta A 2015, 136, 864-870.

117. Darroudi, M.; Sabouri, Z.; Oskuee, R.K.; Zak, A.K.; Kargar, H.; Hamid, M.H.N.A. Green chemistry approach for the synthesis of $\mathrm{ZnO}$ nanopowders and their cytotoxic effects. Ceram. Int. 2014, 40, 4827-4831.

118. Sivaraj, R.; Rahman, P.K.S.M.; Rajiv, G.P.; Venckatesh, R. Biogenic zinc oxide nanoparticles synthesis using Tabernaemontana Divaricate leaf extract and its anticancer activity against MCF-7 breast cancer cell Lines. Int. Conf. Advan. Agric. Biol. Environ. Sci. 2014, 83-85.

119. Zirconium and Zirconium Compounds. Available online: http://www.gezondheidsraad.nl/ sites/default/files/0015059OSH.pdf (accessed on 28 May 2015).

120. Saridag, S.; Tak, O.; Alniacik, G. Basic properties and types of zirconia: An overview. World J. Stomatol. 2013, 2, 40-47.

121. Li, Q.; Deacon, A.D.; Coleman, N.J. The impact of zirconium oxide nanoparticles on the hydration chemistry and biocompatibility of white Portland cement. Dent. Mater. J. 2013, 32, $808-815$. 
122. Takamura, K.; Hayashi, K.; Ishinishi, N.; Yamada. T.; Sugioka, Y. Evaluation of carcinogenicity and chronic toxicity associated with orthopedic implants in mice. J. Biomed. Mater. Res. 1994, $28,583-589$.

123. Jangra, S.L.; Stalin, L.; Dilbaghi, N.; Kumar, S.; Tawale, J.; Singh, S.P.; Pasricha, R. Antimicrobial activity of zirconia $\left(\mathrm{ZrO}_{2}\right)$ nanoparticles and zirconium complexes. J. Nanosci. Nanotechnol. 2012, 12, 7105-7112.

124. Roopan, S.M.; Kumar, S.H.S.; Madhumitha, G.; Suthindhira, K. Biogenic-production of $\mathrm{SnO}_{2}$ nanoparticles and its cytotoxic effect against hepatocellular carcinoma cell line (HepG2). Appl. Biochem. Biotechnol. 2014, doi:10.1007/s12010-014-1381-5.

125. Khan, M.J.; Husain, Q. Influence of $\mathrm{pH}$ and temperature on the activity of $\mathrm{SnO}_{2}$-bound alpha-amylase: A genotoxicity assessment of $\mathrm{SnO}_{2}$ nanoparticles. Prep. Biochem. Biotech. 2014, $44,558-571$.

126. Cho, W.-S.; Duffin, R.; Bradley, M.; Megson, I.L.; MacNee, W.; Lee, J.K.; Jeong, J.; Donaldson, K. Predictive value of in vitro assays depends on the mechanism of toxicity of metal oxide nanoparticles. Part. Fibre Toxiol. 2013, 10, doi:10.1186/1743-8977-10-55.

127. Buesen, R.; Landsiedel, R.; Sauer, U.G.; Wohlleben, W.; Groeters, S.; Strauss, V.; Kamp, H.; Ravenzwaay, B.V. Effects of $\mathrm{SiO}_{2}, \mathrm{ZrO}_{2}$, and $\mathrm{BaSO}_{4}$ nanomaterials with or without surface functionalization upon 28-day oral exposure to rats. Arch. Toxicol. 2014, 88, 1881-1960.

128. Baek, Y.-W.; An, Y.-J. Microbial toxicity of metal oxide nanoparticles $(\mathrm{CuO}, \mathrm{NiO}, \mathrm{ZnO}$, and $\mathrm{Sb}_{2} \mathrm{O}_{3}$ ) to Escherichia coli, Bacillus subtilis, and Streptococcus aureus. Sci. Total Environ. 2011, 409, 1603-1608.

129. Dasari, T.P.; Pathakoti, K.; Hwang, H.-M. Determination of the mechanism of photoinduced toxicity of selected metal oxide nanoparticles $\left(\mathrm{ZnO}, \mathrm{CuO}, \mathrm{Co}_{3} \mathrm{O}_{4}\right.$ and $\left.\mathrm{TiO}_{2}\right)$ to E. coli bacteria. J. Environ. Sci. 2013, 25, 882-888.

130. Goix, S.; Lévêque, T.; Xiong, T.-T.; Schreck, E.; Baeza-Squiban, A.; Geret, F.; Uzu, G.; Austruy, A.; Dumat, C. Environmental and health impacts of fine and ultrafine metallic particles: Assessment of threat scores. Environ. Res. 2014, 133, 185-194.

131. Ko, K.-S.; Kong, I.C. Toxic effects of nanoparticles on bioluminescence activity, seed germination, and gene mutation. Appl. Microbiol. Biotechnol. 2014, 98, 3295-3303.

132. Golinska, P.; Wypij, M.; Ingle, A.P.; Gupta, I.; Dahm, H.; Rai, M. Biogenic synthesis of metal nanoparticles from actinomycetes: Biomedical applications and cytotoxicity. Appl. Microbiol. Biotechnol. 2014, 98, 8083-8097.

133. Landsiedel, R, Ma-Hock, L., Kroll, A.; Hahn, D.; Schnekenburger, J.; Wiench, K.; Wohllben, W. Testing metal-oxide nanomaterials for human safety. Adv. Mater. 2010, 22, 2601-2627.

134. Darolles, C.; Sage, N.; Armengaud, J.; Malard, V. In vitro assessment of cobalt oxide particle toxicity: identifying and circumventing interference. Toxicol. In Vitro 2013, 27, 1699-1710.

135. Djurisic, A.B.; Leung, Y.H.; Ng, A.M.C.; Xu, X.Y.; Lee, P.K.H.; Degger, N.; Wu, R.S.S. Toxicity of metal oxide nanoparticles: Mechanisms, characterization, and avoiding experimental artefacts. Small 2015, 11, 26-44.

136. Adner, D.; Korb, M.; Schulze, S.; Hietschol, M.; Lang, H. A straightforward approach to oxide-free copper nanoparticles by thermal decomposition of a copper(I) precursor. Chem. Commun. 2013, 49, 6855-6857. 
137. Khalil, A.; Jouiad, M.; Khraished, M.; Hashaikeh, R. Facile synthesis of copper oxide nanoparticles via electrospinning. J. Nanomater. 2014, 2014, 438407.

138. Cuevas, R.; Duran, N.; Diez, M.C.; Tortella, G.R.; Rubilar, O. Extracellular biosynthesis of copper and copper oxide nanoparticles by Stereum hirsutum, a native white-rot fungus from chilean forests. J. Nanomater. 2015, 2015, 789089.

139. Wang, J.; Zhang, B.; Wang, L.; Wang, M.; Gao, F. One-pot synthesis of water-soluble superparamagnetic iron oxide nanoparticles and their MRI contrast effects in the mouse brains. Mater. Sci. Eng. C 2015, 48, 416-423.

140. Liu, Y.; Zhang, Y.; Zhang, M.; Zhang, W.; Yang, L.; Wang, C.; Chen, Z. Preparation of nanocrystalline antimony oxide powders by use of gamma-ray radiation-oxidization route. Mater. Sci. Eng. B 1997, 49, 42-45.

141. Zhang, Y.; Li, G.; Zhang, J.; Zhang, L. Shape-controlled growth of one-dimensional $\mathrm{Sb}_{2} \mathrm{O}_{3}$ nanomaterials. Nanotechnology 2004, 15, 762-765.

142. Yamada, H.; Urata, C.; Ujiie, H.; Yamauchi, Y.; Kuroda, K. Preparation of aqueous colloidal mesostructured and mesoporous silica nanoparticles with controlled particle size in a very wide range from $20 \mathrm{~nm}$ to $700 \mathrm{~nm}$. Nanoscale 2013, 5, 6145-6153.

143. Das, D.; Yang, Y.; O’Brien, J.S.; Breznan, D.; Nimesh, S.; Bernatchez, S.; Hill, M.; Sayari, A.; Vincent, R.; Kumarathasan, P. Synthesis and physicochemical characterization of mesoporous $\mathrm{SiO}_{2}$ nanoparticles. J. Nanomater. 2014, 2014, 176015.

144. Arthi, G.; Archana, J.; Navaneethan, M.; Ponnusamy, S.; Hayakawa, Y.; Muthamizhchelvan, C. Solvothermal growth of diethylamine capped $\mathrm{TiO}_{2}$ nanoparticles and functional properties J. Mater. Sci Mater. Electron 2015, 26, 2380-2383.

145. Behnajady, M.A.; Eskandarloo, H. Preparation of $\mathrm{TiO}_{2}$ nanoparticles by the sol-gel method under different $\mathrm{pH}$ conditions and modeling of photocatalytic activity by artificial neural network. Res. Chem. Intermed. 2015, 41, 2001-2017.

146. Rath, M.C.; Naik, D.B. Post-irradiation induction time in the radiolytic synthesis of $\mathrm{UO}_{2}$ nanoparticles in aqueous solutions. J. Nucl. Mater. 2014, 454, 54-59.

147. Zhao, R.; Wang, L.; Gu, Z.J.; Yuang, L.Y.; Xiao, C.L.; Zhao, Y.L.; Cahi, Z.F.; Shi, W.Q. A facile additive-free method for tunable fabrication of $\mathrm{UO}_{2}$ and $\mathrm{U}_{3} \mathrm{O}_{8}$ nanoparticles in aqueous solution. Cryst. Eng. Comm. 2014, 16, 2645-2651.

148. Ali, M.A.; Idris, M.R.; Quayum, M.E. Fabrication of $\mathrm{ZnO}$ nanoparticles by solution combustion method for the photocatalytic degradation of organic dye. J. Nanostructure Chem. 2013, 3, 36.

149. Bai, X.; Li J.; Liu, H.; Tan, L.; Liu, T.; Meng, X. Solvothermal synthesis of ZnO nanoparticles and anti-infection application in vivo. ACS Appl. Mater. Interfaces 2015, 7, 1308-1317.

150. Ghoul, J.E.; Kraini, M.; Mir, L.E. Synthesis of Co-doped ZnO nanoparticles by sol-gel method and its characterization. J. Mater. Sci: Mater. Electron. 2015, 26, 2555-2562.

151. Hajizadeh-Oghaz, M.; Razavi, R.S.; Khajelakzay, M. Optimizing sol-gel synthesis of magnesia-stabilized zirconia (MSZ) nanoparticles using Taguchi robust design for thermal barrier coatings (TBCs) applications. J. Sol-Gel Sci. Technol. 2015, 73, 227-241.

152. Rabjbar, M.; Lahooti, M.; Yousefi, M.; Malekzadeh, A. Sonochemical synthesis and characterization of nano-sized zirconium(IV) complex: New precursor for the preparation of pure monoclinic and tetragonal zirconia nanoparticles. J. Iran Chem. Soc. 2014, 11, 1257-1264. 
153. Sreeremya, T.S.; Krishnan, A.; Satapathy, L.N.; Ghosh, S. Facile synthetic strategy of oleophilic zirconia nanoparticles allows preparation of highly stable thermo-conductive coolant. RSC Adv. 2014, 4, 28020-28028.

154. Bhattacharjee, A.; Ahmaruzzaman, M.; Sinha, T. A novel approach for the synthesis of $\mathrm{SnO}_{2}$ nanoparticles and its application as a catalyst in the reduction and photodegradation of organic compounds. Spectrochim. Acta Mol. Biomol. Spectrosc. 2015, 136, 751-760.

155. Sun, G.; Qi, F.; Zhang, S.; Li, Y.; Wang, Y.; Cao, J.; Bala, H.; Wang, X.; Jia, T.; Zhang, Z. Synthesis and enhanced gas sensing properties of flower-like $\mathrm{SnO}_{2}$ hierarchical structures decorated with discrete $\mathrm{ZnO}$ nanoparticles. J. Alloys Compd. 2014, 25, 192-199.

156. Zamand, N.; Pour, A.N.; Housaindokht, M.R.; Izadyar, M. Size-controlled synthesis of $\mathrm{SnO}_{2}$ nanoparticles using reverse microemulsion method. Solid State Sci. 2014, 33, 6-11.

(C) 2015 by the authors; licensee MDPI, Basel, Switzerland. This article is an open access article distributed under the terms and conditions of the Creative Commons Attribution license (http://creativecommons.org/licenses/by/4.0/). 